\title{
CAMILLO GOLGI
}

PROFESSOR OF PATHOLOGY AT THE UNIVERSITY OF PAVIA, SAVANT AND CITIZEN, GUARDIAN OF PUBLIC HEALTH AND STUDENT OF HISTOLOGY, TO WHOM THE WORLD IS INDEBTED FOR A METHOD WHICH GAVE A DEEPER INSIGHT INTO THE ARCHITECTURE OF THE CENTRAL NERVOUS SYSTEM-THIS VOLUME OF THE JOURNAL OF COMPARATIVE NEUROLOGY IS DEDICATED AS A TOKEN OF HIGH ESTEEM FOR THE SCIENTIST AND THE MAN WHO, HONORED AND FULL OF YEARS, NOW WITHDRAWS FROM HIS PROFESSORIAL RESPONSIBILITIES 
Resumido por el autor, Olof Larsell.

Estudios sobre el nervio terminal. Mamíferos.

El autor describe con algún detalle el nervio terminal en el gato, buey y mulo, dando también descripciones más breves de dicho nervio en el caballo, perro, ardilla y en el hombre. En el buey, mulo y ardilla se describe este nervio por primera vez. En los mamiferos está formado principalmente por fibras del simpático; las del fascículo principal del nervio tienen con las que se distribuyen periféricamente una relación semejante a la que existe entre las fibras preganglionares y postganglionares. Esta semejanza está aumentada por la estructura de los racimos ganglionares y por la presencia de cestas pericelulares en muchas de las células ganglionares. También existen redes intercelulares y células típicas del simpático. Por la arteria cerebral anterior y sus ramas y por el plexo vascular del tabique nasal se distribuyen fascículos de fibras mielínicas y amielínicas procedentes del tronco principal y ganglios. Estas fibras terminan en las paredes de los vasos sanguíneos por medio de terminaciones nerviosas sensitivas y motrices. Hay algunas pruebas de que las terminaciones nerviosas libres en el epitelio nasal están relacionadas con el nervio terminal, pero la presencia indudable de fibras del trigémino en el plexo del tabique, junto con las procedentes del terminal, no permite una afirmación rotunda sin previo trabajo experimental. Estas terminaciones, junto con las de ciertas células ganglionares parecen indicar la existencia de un componente sensitivo en el nervio, distinto de las fibras aferentes del simpático. Parece claro que la inervación del organo de Jacobson por parte del nervio terminal es incidental y secundaria. El autor expone la posibilidad de que el nervio terminal represente una división del sistema del simpático, relacionada con el cerebro anterior.

Translation by Dr. José Nonidez,

Columbia University 


\title{
STUDIES ON THE NERVUS TERMINALIS: MAMMALS
}

\author{
OLOF LARSELL \\ Department of Anatomy, University of Wisconsin \\ FORTY-NINE FIGURES
}

CONTENTS

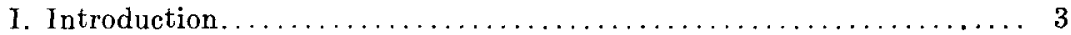

Discovery and naming................................ 3

Conditions in the different classes of vertebrates............. 5

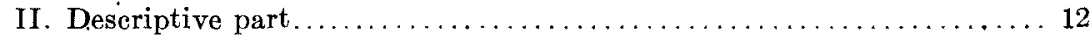

Material and methods .............................. 12

1. The nervus terminalis of the cat.................... 16

Histological. . . . . . . . . . . .

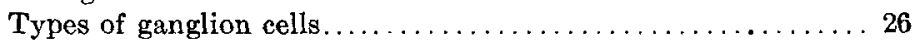

Fibers and fiber networks........................ 33

Nerve terminations.......................... 37

2. The nervus terminalis of the beef $\ldots \ldots \ldots \ldots \ldots \ldots \ldots \ldots \ldots, 43$

Histological ................................. 48

Structure of nerve bundles. ....................... 48

Nerve terminations............................, 50

3. The nervus terminalis of the mule and the horse $\ldots \ldots \ldots \ldots \ldots \ldots, 51$

The mule..................................... 51

Histological ................................ 55

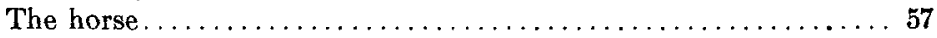

4. The nervus terminalis of the dog, the squirrel, the human, and of embryos of pig, sheep, and rabbit................... 61

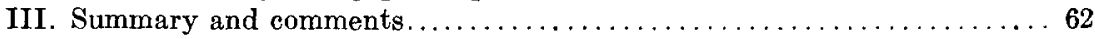

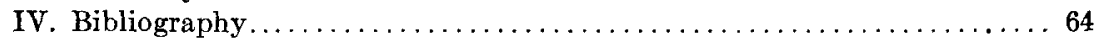

\section{INTRODUCTION}

Discovery and naming. The cerebral nerve now known as the nervus terminalis first began to attract the attention of morphologists in 1894. In that year Pinkus described in the dipnoan fish, Protopterus, a hitherto unrecognized nerve of the forebrain.

${ }^{1}$ Contribution from the Zoological Laboratory of Northwestern University, William A. Locy, Director. 
This nerve had previously been figured by Fritsch in the selachian, Galeus, in 1878, and had been mentioned in 1893, by C. L. Herrick in the urodele amphibian, Necturus. The observations of Fritsch and Herrick, however, were merely incidental, in connection with other work, and the significance of the observations escaped them.

After these anticipatory glimpses the nerve remained unnoticed until Pinkus described it in Protopterus in 1894. In. 1895, in a more extended paper, Pinkus figured and described it as lying ventral to the olfactory nerve and extending caudad over the ventral surface of the forebrain to the recessus praeopticus, its peripheral terminations being in the olfactory sac. Thus, although first figured in selachians, it was first described with sketches, in the Dipnoi.

Shortly afterward, Allis ('97) deseribed and figured in the ganoid fish, Amia, a strand which he traced centrally to the bulbus olfactorius and peripherally to the olfactory capsule. He considered this strand to be homologous with the nerve described by Pinkus. In his comments regarding the possible function of the nerve, he suggested that it might be of sympathetic type. This is interesting in view of the position taken by Brookover and others and of the demonstration of the presence of sympathetic fibers in the bundle of the nervus terminalis of mammals.

Now appeared the first study of the embryological history of the nerve (Locy, '99) together with a description of its adult condition in Squalus acanthias. In this form the nerve was described and figured as possessing a compact ganglion, as connected with the brain in the fissure between the lobes of the telencephalon, and as distributed anteriorly to the lateral part of the olfactory capsule and entering between the folds of the nasal epithelium. It was claimed that the nerve arises from the neural crest before the appearance of the olfactory fibers. At that time Locy considered as doubtful its homology with the nerve described by Pinkus, and provisionally designated it as a median 'accessory olfactory strand.' In 1903, after observing the same nerve in six genera of selachians, Locy reversed his earlier opin- 
ion and concluded that the nerve of selachians is homologous with that described by Pinkus in Protopterus and later by Allis in Amia. The same author in his paper of 1905, based on the examination of twenty-seven species of adult selachians and the embryological history of the nerve in Squalus, proposed the name of 'nervus terminalis' for this new nerve. This name has been generally adopted.

In the interval Sewertzoff ('02) had described the nerve in embryos of Ceratodus, finding it ganglionated and terminating peripherally in the mucous membrane of the anterior nasal chamber-not in the sensory epithelium. On account of its point of central connection with the brain he suggested for it the name of 'nervus praeopticus.' This nerve had also been cited in the adult of Ceratodus by K. Fürbringer in 1904, as well as by Bing and Burckhardt in 1904 and 1905.

Conditions in the different classes of vertebrates. Since 1905 a considerable literature has accumulated regarding the nervus terminalis. Its presence has been demonstrated in all cases of vertebrates except the cyclostomes (and possibly the birds) and various suggestions regarding its function have been made from time to time.

Inasmuch as the present paper deals with the nervus terminalis chiefly in mammals, it is not necessary to enter into a review of the rather extensive literature of the nerve in the lower vertebrates, But, since the nerve presents some modifications and some differences in the mammals, it is advantageous both for comparison and for discussion of results, to have a brief statement of the chief structural features which have been observed in other classes of the phylum. The nervus terminalis appears to be more generalized in the fishes, especially in the selachians, and in discussing its relations in mammals it would be a mistake to disregard the findings in the lower vertebrates.

Fishes: a) Selachians. In a paper on the telencephalon of the selachians, Johnston ('11) shows that typically the nervus terminalis enters the brain substance near the recessus neuroporicus internus. He remarks: "Some evidence has appeared recently (Burckhardt, '07, p. 340; Brookover, '10) that the nervus ter- 
minalis is a mixed nerve, containing in some fishes peripheral sympathetic fibers distributed to the blood-vessels. These efferent fibers make their exit in a dorsal root ( $N$. terminalis) as the viscero-motor fibers typically do in the spinal region of lower vertebrates."

Belogolowy ('12), from a study of young selachian embryos, concludes that the nervus terminalis is derived from the terminal portion of the neural crest. This was also claimed by Locy ('99) and ('05 a).

McKibben ('14) studied the histological structure of the ganglion terminale of Mustelus by intravitam methylene-blue staining. He found the great majority of the cells to be multipolar and "few if any bipolar cells." Landacre ('16), from observations on Squalus embryos, holds that the terminalis is combined with the olfactorius as a possible general cutaneous component of the latter.

b) Ganoids. Through the studies of Brookover ('08 and '10) we have very complete reports of the terminalis for the ganoid fish Amia. He concludes that the ganglion of the terminalis arises from the olfactory placode a little later than do the fibers of the olfactory nerve. He doubts its independence and is disposed to consider it a part of the olfactory system. In histological observations he finds ganglion cells chiefly of sympathetic type. He also finds fibers along the blood-vessels and a connection between the terminalis fibers and the ciliary ganglion, and suggests that the circumstantial evidence leads one to ascribe to it a vasomotor function, in part. The same author gets similar results from Lepidosteus ('14) where the ganglion terminale appears to arise from the olfactory placode after the formation of the olfactory fibers. "The disposition of the cells in Lepidosteus in a more compact central and a diffuse peripheral ganglion allows of its falling quite naturally into the morphological relations of the typical autonomic system."

This shows the tendency toward interpreting the terminalis as sympathetic in nature (or at least as containing sympathetic fibers) which becomes more marked in studies of the mammals. 
c) Teleosts. The presence of the nervus terminalis in bony fishes was first reported by Sheldon and Brookover ('09) in the carp (Cyprinus carpio). Sheldon ('09) independently takes up the central course of the nerve. The tract is composed of unmyelinated fibers. Numerous scattered ganglion cells were found on the ventromedial aspect of the olfactory nerve, from some of which coarse fibers were traced to the olfactory epithelium where they were distributed with the olfactory nerve fibers. Centrally the fibers for the most part decussate at the anterior commissure, but no exact nuclear connection could be found.

Brookover and Jackson ('11) studied the development of the terminalis in Ameiurus, and also its adult relations by means of the silver-impregnation methods. They find the nerve to be closely related in its development to the olfactory nerve and are inclined to consider it a part of this rather than as an independent nerve. They point out the proximity of fibers of the nervus terminalis to blood-vessels, but find only a single instance where the blood-vessel definitely appeared to be innervated by terminalis fibers. A vasomotor functon is suggested.

Amphibia. C. Judson Herrick ('09) found in larval and adult frogs a bundle of unmyelinated fibers corresponding so closely to the nervus terminalis of the fishes in its central course that he considered it to be homologous with the latter. He was unable from his material to determine peripheral terminations. The nerve is not exposed as in selachians: It runs along the ventral, border of the olfactory nerve and becomes imbedded in the brain substance just caudad to the glomerular formation. Within the brain substance it passes caudally (in one case showing arborizations in the lamina terminalis) and the fibers cross in the middle part of the anterior commissure.

McKibben ('11) traces the course of the nervus terminalis in Necturus and a number of other tailed amphibians. As in the frog, it is mainly imbedded in the brain substance. The principal central distribution is to the preoptic nucleus. The central bundle undergoes a partial decussation in the anterior commissure, but groups of direct fibers extend further backward from this point, giving off branches at intervals. The continuity of 
these fibers with those of the nervus terminalis was not clearly demonstrated. The fiber groups were lost in the brain substance without evidence of definite terminations, though the fascicles. reach backward into the mesencephalon (hypothalamus and interpeduncular region), a condition not yet noted in other forms. Peripherally are ganglion cells with fibers going apparently to the nasal capsules.

C. Judson. Herrick ('17), in connection with other studies, has completely confirmed in Necturus the findings of McKibben.

Reptilia. Among reptiles the nervus terminalis has been found by Johnston ('13). In a paper, which embraces also a consideration of the nerve in pig, sheep, and human embryos, he describes the terminalis in embryos of the turtle (Emys lutaria). In Emys the nerve emerges from the rostral end of the median wall of the brain hemisphere, caudal to the olfactory bulb. From this point "It descends over the medial surface of the bulb and olfactory nerve and bears clumps of ganglion cells at several points of its course. It comes into close relation with the dorsal division of the olfactory nerve, but is distinguished from it." Peripherally the fibers of the nervus terminalis are distributed with those of the dorsal division of the olfactory nerve to the extreme lateral portion of the nasal sac, which is interpreted by Johnston to correspond with the vomeronasal organ of mammals.

According to McCotter ('17), the dorsal division of the olfactory nerve of the turtle is to be considered homologous with the vomeronasal nerve of mammals, and the dorsal portion of the formatio olfactoria of the bulb, as illustrated in Johnston's figure 11, corresponds to the accessory olfactory bulb of mammals.

Birds. Whether or not the ganglion cells observed by Rubaschin ('03) in the chick embryo represent cells of the nervus terminalis is problematical. This writer describes a ganglionic mass related on the one hand to the trigeminus nerve and on the other to the olfactory mucosa. Axones from this mass were traced to the Gasserian ganglion. Two types of cells were found in the ganglionic knots: 1) bipolar cells resembling those of the intervertebral ganglia, and 2) multipolar cells with numerous proc- 
esses, of which one in each case enters the 'ramus olfactorius nervus trigemini.' Cells of this type are relatively few in number. These observations have been interpreted by some writers to indicate the presence of the nervus terminalis in birds.

Mammals. Since 1905 the nervus terminalis of mammals has been dealt with in no less than nine scientific memoirs. In some cases it has been confused with the fibers of the vomeronasal nerve (Devries, '05; Döllken, '09), but in most cases the fibers of the terminalis are distinguished from those of the vomeronasal. Notwithstanding these investigations, the nervus terminalis in the mammals is very imperfetly known and its relations are obscure.

The first published notice of this nerve in the mammals was made by DeVries in 1905. He found in the human fetus of three to four months a transitory ganglion which he regarded as corresponding to the ganglion of the nervus terminalis, and which he designated 'ganglion vomero-nasale.' He also found similar conditions in the guinea-pig. His assumption that the vomeronasal nerve of mammals represents the nervus terminalis of selachians and other fishes is not substantiated by more recent work.

Döllken ('09) studied embryonic stages of rabbit, mouse, guineapig, pig, and human. His account of the central connections of what he describes as the nervus terminalis is extended. He finds roots which enter the brain and reach the cortex, the gyrus fornicatus, the hippocampus, and the septum pellucidum. The peripheral distribution he describes as being by four or five strands to the vomeronasal organ. It seems clear from his description and figures that he is dealing almost entirely, if not completely, with the vomeronasal nerve, which Read ('08) and McCotter ('12) have clearly differentiated from the olfactory fibers proper in mammals, and McCotter ('17) in the turtle and the frog.

In a paper already referred to in connection with the nervus terminalis in reptiles, Johnston ('13) also describes the nerve in embryos of pig, sheep, and human. In pig embryos he finds the root of the terrninalis entering the brain at the ventral end of the fissura prima. The fibers are traceable for some distance within 
the brain toward the anterior commissure. The peripheral course of the nerve is described as being in the wall of the septum nasale, along which it passes by several strands to the wall of Jacobson's organ and to a small area of the nasal sac immediately adjacent.

In the human embryo Johnston found essentially the same central relations as in the pig, but the peripheral distribution is by a network of nerve bundles in the nasal septum.

He concludes that "the evidence at present in hand seems to establish beyond doubt the presence in all vertebrates of a receptive component in the nervus terminalis supplying ectodermal territory. This component is derived either from the terminal part of the neural crest (Johnston, '09 b; Belogolowy, '12) or from the olfactory placode (Brookover, '10). The nerve is distributed to the nasal mucosa, or to a specialized part of it, the vomeronasal organ."

McCotter ('13) demonstrated by dissection the main central bundle of the terminalis in the adult dog and cat. He also found the typical ganglion cells of the nerve distributed along the vomeronasal strands. No differentiation of fibers from those of the vomeronasal nerve was obtained by the staining methods used.

The application to the problem of a modified pyridin-silver technique by Huber and Guild ('13), served to clearly differentiate the terminalis from the vomeronasal nerve. These investigators used rabbit fetuses and young rabbits. They were fortunate in securing a differential stain which made it possible to follow the fibers of the two sets of nerves individually. They conclude that

this nerve is not a component of the olfactory and vomero-nasal complex, but an independent nerve, with central connections by means of several small roots to the ventro-mesial portion of the forebrain, caudal to and independent of the olfactory stalk, and courses in the form of a loose plexus along the ventro-mesial surface of the olfactory bulb, reaching the nasal septum and the mesial surface of the vomero-nasal nerve, which nerve it follows to the vomero-nasal organ, and is further distributed to the septal mucosa anterior to the path of the vomeronasal nerve, in which region especially it is joined by terminal branches of the trigeminus, mainly from the naso-palatine bundles. 
Numerous ganglionic masses of various sizes are found. One group of relatively large size located near the most caudad bundle of the vomeronasal nerve a short distance from where the latter leaves the accessory olfactory bulb is regarded as the ganglion terminale of authors. These groups of ganglion cells present the appearance of small sympathetic ganglia, and the authors state that the nerve fibers have more the appearance of sympathetic and preganglionic fibers than of neuraxes and dendrites of sensory neurones. A comparison of these cells with the cells of the Gasserian ganglion of the same animals revealed the fact that the terminalis cells are of smaller size.

Distribution of terminalis fibers to blood-vessels and septal mucosa was considered probable from the observations, but the authors hesitated to assert such distribution because of the commingling of fibers from the trigeminus with those of the nervus terminalis.

Johnston ('14) describes the central relations of the terminalis in the adult human, in the horse, porpoise, and the sheep. $\mathrm{Nu}$ merous rootlets were found in some, especially in the horse, while in other forms only two or three are enumerated. In the horse, a large, compact ganglion is described. In the other mammals the ganglionic masses are described as being smaller but more numerous, and more or less scattered along that portion of the nerve which it was possible to examine.

Brookover ('14) independently of Johnston discovered the central portion of the nerve in the brain of the adult human, and reached substantially the same conclusions as to central connections as did Johnston, namely, that its intracranial course lies over the middle of the gyrus rectus and appears to enter the brain substance in the region of the medial olfactory striae.

Both central and peripheral distribution in the human fetus is described by McCotter ('15). He indicates the peripheral course in the nasal mucosa, where it resembles in general the conditions found by Huber and Guild in the rabbit. Centrally the majority of the fibers form a single strand.

The latest paper which has come to notice has appeared since the greater part of the observations recorded in the present ar- 
ticle were made. In this paper Brookover ('17) describes the peripheral distribution of the terminalis in the nasal septum of the human fetus at full term. This material was prepared by the pyridin-silver method.

A large plexus of fibers is found anastomosing over the nasal septum deep to the main arteries. The writer states that this network "is so large that it may be considered as hypertrophied as compared to the known development in other mammals, without apparently increasing the central root." There are indications of a sympathetic chain connection with the sphenopalatine nerve and ganglion.

It seems clear that in selachians, Dipnoi, ganoids, teleosts, Amphibia, reptiles (turtle at least), and mammals there is common to all a nerve with central connections with the brain near the embryonic anterior neuropore, and having a primary peripheral distribution to some part of the lining of the nasal cavity.

\section{DESCRIPTIVE PAR'T}

Material and methods. The original design of this investigation was to make a comprehensive analysis of the nervus terminalis in the various classes of vertebrates. More difficulties of analysis and interpretation are encountered in mammals than in the other groups, so that the present contribution is limited in its scope to the conditions found in certain mammals, with the expectation of extending these observations in a subsequent paper to other classes.

The studies were carried on in the Zoological Laboratory of Northwestern University from 1915 to 1918, inclusive, under the direction of Prof. William A. Locy, to whom I express my sense of indebtedness for helpful advice and criticism. My thanks are also due Prof. S. W. Ranson, of Northwestern University Medical School, for valuable suggestions.

The mammalian material used consists of the following:

1 longitudinal and 1 transverse series of $10 \mathrm{~mm}$. kitten embryos, fixed in 10 per cent formalin and stained with hacmatoxylin.

1 sagittal series through forebrain and nasal septum of kitten one day old, treated by the pyridin-silver process. 
1 sagittal series through forebrain and nasal septum of kitten two weeks old, pyridin-silver method.

2 sagittal series of nasal septum of kittens two weeks old, pyridin-silver method. 1. sagittal series through forebrain and nasal septum of kitten one day old, fixed and decalcified in Zenker's fluid and stained by the Weigert method.

2 septal mucosae of kitten one day old, stained with methylene-blue.

Numerous series of pig embryos at various stages, stained with haematoxylin or with Mallory's connective tissue stain.

In addition to these sections, the following materials were also studied according to the method indicated: Numerous dissections of kittens, of puppies, and of adult dogs and cats were made. The method described by McCotter, by which the head is fixed in Müller's fluid to which acetic acid has been added, was used with good results. Fixation in 10 per cent formalin, followed by decalcification in 10 per cent nitric acid, was also adopted in many instances. A light surface stain with borax-carmine was found advantageous in -differentiating the nervus terminalis from the neighboring tissues.

Frozen beef brains were obtained from the Chicago Stock Yards, and were found to be very favorable for the dissection of the delicate strands of the nervus terminalis. These refrigerated brains were allowed to thaw in a solution of 10 per cent formalin at room temperature. Besides being relatively easy to dissect, this material responded well to the gold-chloride technique and gave excellent histologic preparations. A number of beef fetuses of $110 \mathrm{~mm}$. to $140 \mathrm{~mm}$. greatest length were also dissected. These had been preserved in formalin. Supplementary studies were made on beef material from which the meninges and a portion of the brain beneath the region of the nervus terminalis were removed and fixed in 1 per cent osmic acid, immediately after the brain was taken from the cranial cavity. Most of the material thus obtained was still warm when fixed. It was made possible to obtain this through the courtesy of Swift \& Company.

The brain of a full-term mule, freshly removed and fixed in 10 per cent formalin, was obtained. Another mule fetus of 121 $\mathrm{mm}$. greatest length was also studied. The brain, in situ, and the nasal septum of an adult horse was obtained through the 
courtesy of the Chicago Veterinary College. This was fixed in 10 per cent formalin and decalcified in nitric acid.

A number of dissections of pig, rabbit, and sheep embryos were made. Most of these were treated according to the method given by Prentiss ('15).

Opportunity to examine twelve human brains was obtained through the courtesy of Prof. S. W. Ranson. It was attempted to ascertain if the relations of the fibers of the nervus terminalis to the cerebral blood-vessels is the same in the human as in the cat, the mule, and the ox. The nerve was identified in five of the brains, but no definite light was obtained on the point in question.

\section{ABBREVIATIONS}

ant.cer.art., anterior cerebral artery

art.w., arterial wall

$a x .$, axone

ax.cyl., axis cylinder

bi.c., bipolar cell

$b l . v .$, blood-vessel

bu.olf., bulbus olfactorius

bu.olf.ac., accessory olfactory bulb

cen., centripetally

cer.hem., cerebral hemisphere

co.ant., anterior commissure

c.pr., central process

cri.pl., cribriform plate

d.n.ter., dorsal main bundle of nervus terminalis in nasal septum

fi., nerve fiber

gn., main ganglion ('ganglion terminale') of nervus terminalis

$g n^{\prime}$, , accessory ganglia

in.pl., intracranial plexus of nervus terminalis

lam.ter., lamina terminalis

m.n.ter., median main bundle of nervus

terminalis in nasal septum

$m y .$, myelinated nerve fiber

my.sh., myelin sheath

n.eth.ant., anterior ethmoidal nerve

n.op., optic nerve
no.R., node of Ranvier

n.ter., nervus terminalis

n.vom., nervus vomeronasalis

olf.fi., olfactory fibers

op.chi., optic chiasma

or.vom., vomeronasal organ

per., peripherally

$p . p l$, peripheral (septal) plexus of nervus terminalis

$p . p r .$, peripheral process

$p r .$, nerve process

$R .$, fiber of Remak

$r^{1}, r^{2}, r^{3}, r^{4}$, central roots of nervus terminalis

ram., ramus

$r . d o r .$, ramus of dorsal main bundle of nervus terminalis

resp.epith., respiratory epithelium

r.med., ramus of middle main bundle of nervus terminalis

r.ven., ramus of ventral main bundle of nervus terminalis

$s p .$, spiral

un.c., unipolar cell

unmy., unmyelinated nerve fiber

$v . n . t e r .$, ventral main bundle of nervus terminalis 
Turtle embryos and young of Amia were prepared by various methods and a number of dissections were also made.

For nerve terminations the gold-chloride method was employed, according to the modification given by Hardesty. Methylene-blue was tried, but with less success in demonstrating the sensory terminations to be described, although it brought out

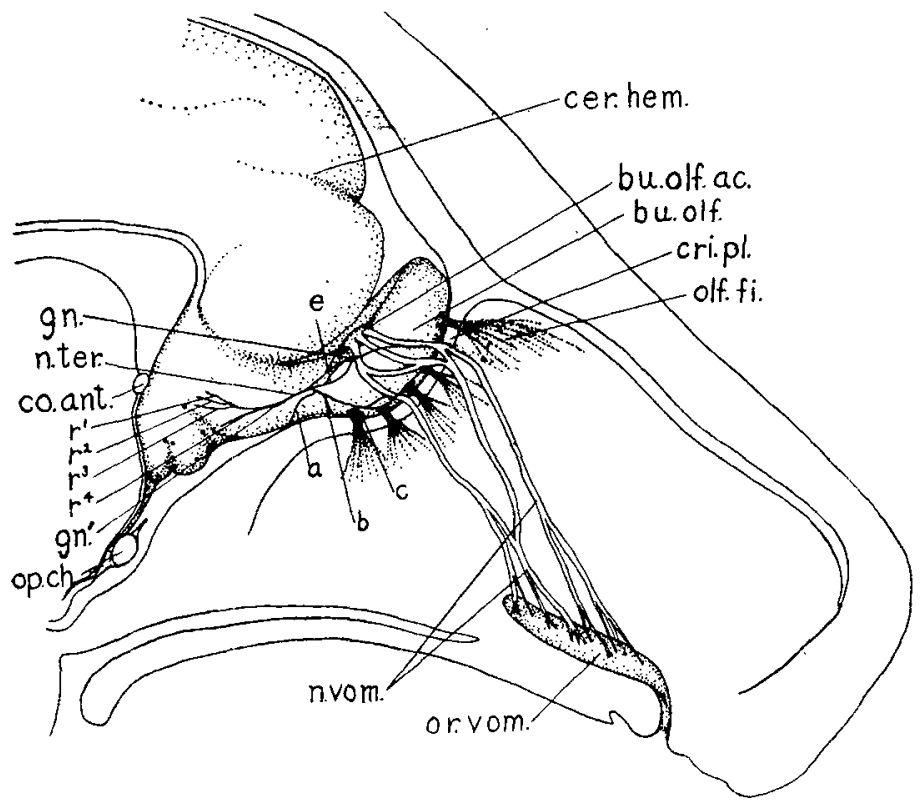

Fig 1 Dissection of nervus terminalis of kitten of two weeks, illustrating plexiform appearance of nerve, as seen through the binocular microscope. The blood-vessels, along which the majority of the nerve strands course, are not represented.

the motor endings quite clearly. Both sensory and motor terminations were shown in pyridin-silver preparations.

A modification of the pyridin-silver method given by Huber and Guild ('13) was used with good results. This modification consisted essentially in lengthening the periods during which the preparation was kept in the various fluids. Briefly summarized, the procedure was as follows: Ammoniated absolute alcohol 
(after injection with same) seven days; decalcification in 7 per cent nitric acid; washing; 80 per cent, 95 per cent, and absolute alcohols with 1 per cent ammonia added to each, ten days altogether, to insure thorough dehydration; pyridin four days; silver nitrate, after washing, ten days; four per cent pyrogallol in 5 per cent formalin two days. All of these fluids except the last, were changed several times. In several of the preparations the strength of the silver solution was varied, beginning with a solution of 2 per cent for several days, then reducing to 1 per cent, to 0.75 per cent, and finally back to 2 per cent. The results in the way of details of structure and of staining the finer fibers, which were obtained by this modification were superior to those given by the unmodified procedure.

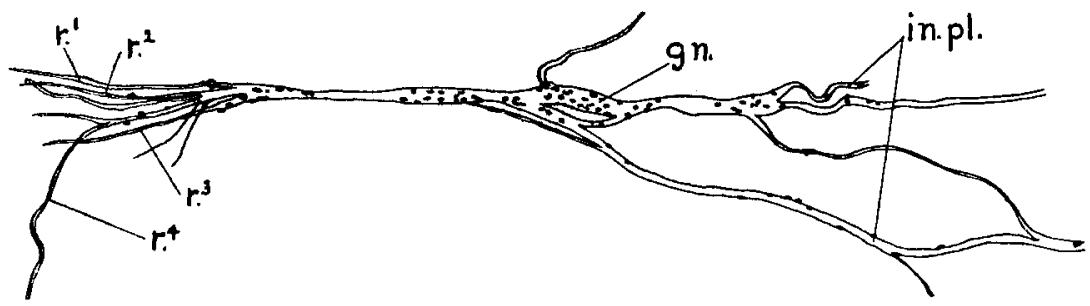

Fig. 2 Right nervus terminalis from same kitten of which the left nerve is shown in figure 1 . Removed and mounted entire. $\times 32$.

\section{The nervus terminalis of the cat}

The nervus terminalis of the cat is found on the medial side of the olfactory stalk. The main trunk runs parallel with the ventral border of this, stalk, between the fissura prima of the forebrain and the vomeronasal nerves. As shown in figure 1, which represents the mesial aspect of the forebrain and nasal septum of a kitten of two weeks, the nerve is connected with the brain by three strands $\left(r^{1}, r^{2}, r^{3}\right)$. They follow closely parallel to blood-vessels of small calibre, which enter the brain near the fissura prima. When these vessels were cut at their points of entrance into the brain, the nerve strands also became detached. This was due to the minuteness of the strands which it was not found possible to sufficiently disentangle from the connective tis- 
sues surrounding both vessels and nerves. Sections (figs. 3 and 23) indicate that the larger strands at least enter the brain independently of the blood-vessels.

A fourth strand $\left(r^{4}\right)$, which joins the nerve trunk, appears not to enter the brain. This strand was traced caudally for a short distance along the anterior cerebral artery, but became so attenuated by separating into minute bundles of fibers that it was not possible to follow the divisions far.

In one of the specimens examined, a kitten one day old, cells similar to ganglion cells were observed along the course of the roots for a little distance within the brain (fig. 23).

An elongated ganglionic swelling (fig. 1, gn') is shown rostrad to the point where the nerve strand from the anterior cerebral artery unites with the main trunk of the nerve. Further rostrad a larger ganglion $(g n)$ is seen in close proximity to the most caudal of the three principal vomero-nasal bundles.

Between these two ganglionic masses the main trunk of the nerve breaks up into a plexus of nerve strands $(a, b, c)$. Many of these follow the larger blood-vessels of the region and send twigs into their walls. Three of the largest strands of the plexus converge distally, uniting with vomeronasal bundles. A number of strands, finer than any represented in the figure were found, but were torn in dissection. They were composed of relatively few fibers each, and uniting with the larger strands, formed a loose plexus over the medial surface of the olfactory bulb, as shown in figure 3.

The more ventrally located (c) of the larger bundles divides into two strands which unite, one with the ventral bundle of the vomeronasal nerve, the other with a more dorsally lccated bundle of the same nerve.

While the three strands $(a, b, c)$, already noted, diverge at various angles from the principal axis of the nerve, the other divisions do not depart so widely. As shown in figure 1 (e), they form a secondary plexus which reunites, with the exception of one small strand, into the ganglionic swelling ( $g n$ ) already noted. The single bundle which continues rostrally from this ganglion crosses two of the vomeronasal bundles to become en- 


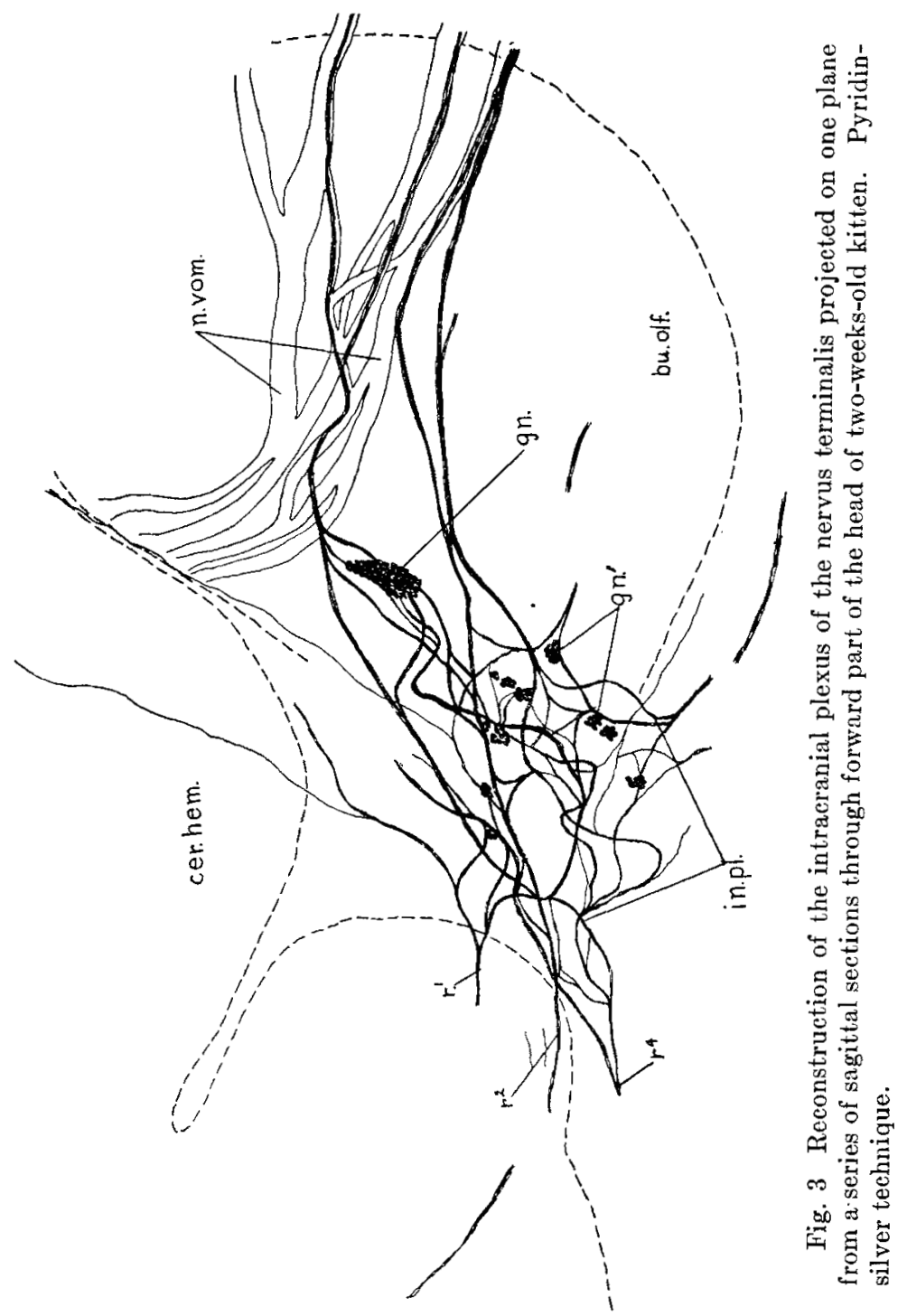


cased within the same connective tissue sheath which surrounds the third, more rostrally situated, vomeronasal bundle. The small strand which fails to reunite with the plexus appeared to have been torn from its course distally along a blood-vessel which passes between the dorsal surface of the olfactory bulb and the cerebral hemisphere.

Essentially the same relations to the vomeronasal nerves and to the cribriform plate were found in a dissection of a half-grown kitten, not figured. In this specimen the left olfactory bulb was removed, and it was attempted to trace strands of the terminalis into the nasal septum. Six strands which clearly belong to the nervus terminalis were present. Four of these became related to the vomeronasal nerves, and one of these four remained sufficiently separated from the dorsal bundle of this nerve so that its course could be followed distinctly through the cribriform plate. Most of the strands became enclosed by the sheaths of the vomeronasal bundles in such a manner that it was not possible to distinguish them from the strands of the latter nerve in their course peripherally by the method of dissection. Two of the strands which passed more dorsally did not converge with the vomeronasal bundles. One of these passed through one of the more dorsally situated foramina of the cribriform plate, together with a large olfactory bundle, and its course on the nasal septum was traced for some distance. The other continued dorsally and became attached to an artery which lay in the furrow between the olfactory bulb and the cerebral hemisphere.

Figure 3, which represents a graphic reconstruction of the terminalis plexus between the vomeronasal nerves and the point where its roots enter the brain, shows essentially the same relations. This figure represents a composite of thirteen sections of the region of the forebrain and nasal septum of a kitten two weeks old, prepared by the pyridin-silver method. It supplements figure 1 by showing the finer strands of the plexus to which reference was made, and by bringing out numerous small ganglia which could not be seen in the dissection represented in figure 1. A comparison of figure 3 with figure 2, which represents an in toto amount of the right nervus terminalis of the same 
kitten from which figure 1 was drawn, is interesting in showing the same manner of distribution of the larger strands as is seen in the reconstruction. It also indicates, somewhat more clearly, the position of the ganglion cells along the main trunk of the nerve. This specimen differs from the one illustrated in figure 3 in that the main ganglionic mass $(g n)$ has fewer ganglion cells than are present in the corresponding ganglion ( $g n$, fig. 3 ) of the other kitten of the same age. More numerous cells, however, are scattered along the nerve trunk, so that the total number is approximately the same in the two specimens, if the smaller ganglia, not observed in the dissected animal, are left out of consideration in both.

The finer strands, which radiate in various directions from what may be designated the central bundle, follow along or soon reach, blood-vessels of various sizes. Many similar strands, consisting of but three or four fibers could not be seen with the low magnification of the projection apparatus used in plotting the figure, and are not included in this reconstruction. These, if represented, would make the plexus much more intricate, especially in its rostral part, and would cause it to extend further rostrally over the olfactory bulb than is figured.

The course of the nervus terminalis in the nasal septum was followed to best advantage in methylene-blue preparations, fixed in ammonium-picrate and mounted in a mixture of ammonium picrate and glycerine.' The silver preparations brought out more clearly the finer strands, but the distortion of the septum produced by this technique made it difficult to follow the general course of the various branches by the method of reconstruction.

The nasal septum of a kitten one day old was removed and was kept moistened for forty minutes in a 0.25 per cent solution of methylene-blue in physiological salt solution. The preparation was examined from time to time until a differentiation was observed between the main bundles of the vomeronasal nerves and the smaller bundles which course parallel to them and which had previously appeared to be part of them. These smaller bundles assumed the blue color characteristic of this stain, while the vomeronasal nerves remained practically unstained. After 
fixation over night in ammonium-picrate, the mucosa was removed from the bony septum and was mounted whole. This was done with the mucosa from both sides of the septum. The two sides showed essentially the same picture, but the right side was somewhat clearer, and is illustrated in figure 4 .

In this specimen the vomeronasal nerves $($ n.vm.) consist of three principal bundles in their proximal course on the septum. About midway toward the organ of Jacobson, which could not be removed with the mucosa without too great danger of injury to the latter, two of these bundles divide into secondary strands. These strands continue to the vomeronasal organ. Parallel with the vomeronasal bundles and in close proximity to them for some distance are the main strands of the nervus terminalis. These strands pass through the cribriform plate, as previously shown in the dissections and as verified by pyridin-silver preparations, in company with the vomeronasal bundles. They continue parallel with them for some distance (fig. 4, n.ter.) and then divide, forming an intricate plexus in the deeper part of the mucosa (fig. 4, p.pl.). Comparison with silver preparations of the nasal septum makes it evident that only a portion of the plexus was stained in this specimen. This portion was derived chiefly from the most dorsal (d.n.ter.) of the principal terminalis strands present. The median of these strands (m.n.ter.) gives off some small twigs of fibers which anastomose with the main trunk of the dorsal bundle, and more rostrad it breaks up into branches, one of which (r.med.) forms a portion of the plexus. A larger branch of this median bundle continues parallel with the median branch of the vomeronasal bundle, but could be followed for only a short distance rostrally. The most ventral bundle of the terminalis (v.n.ter.), which is also the largest, was lost distally because of the idiosyncrasy of the stain. A small twig ( $r$. ven.) given off in the more proximal part of its course passes beneath the ventral vomeronasal bundle and is soon lost in the mucosa ventral to this bundle. A large branch (r.dor.) from the dorsal terminalis bundle also courses ventrally, but this could not be traced beyond the dorsal ramus of the ventral vcmeronasal bundle. All other branches which were stained 


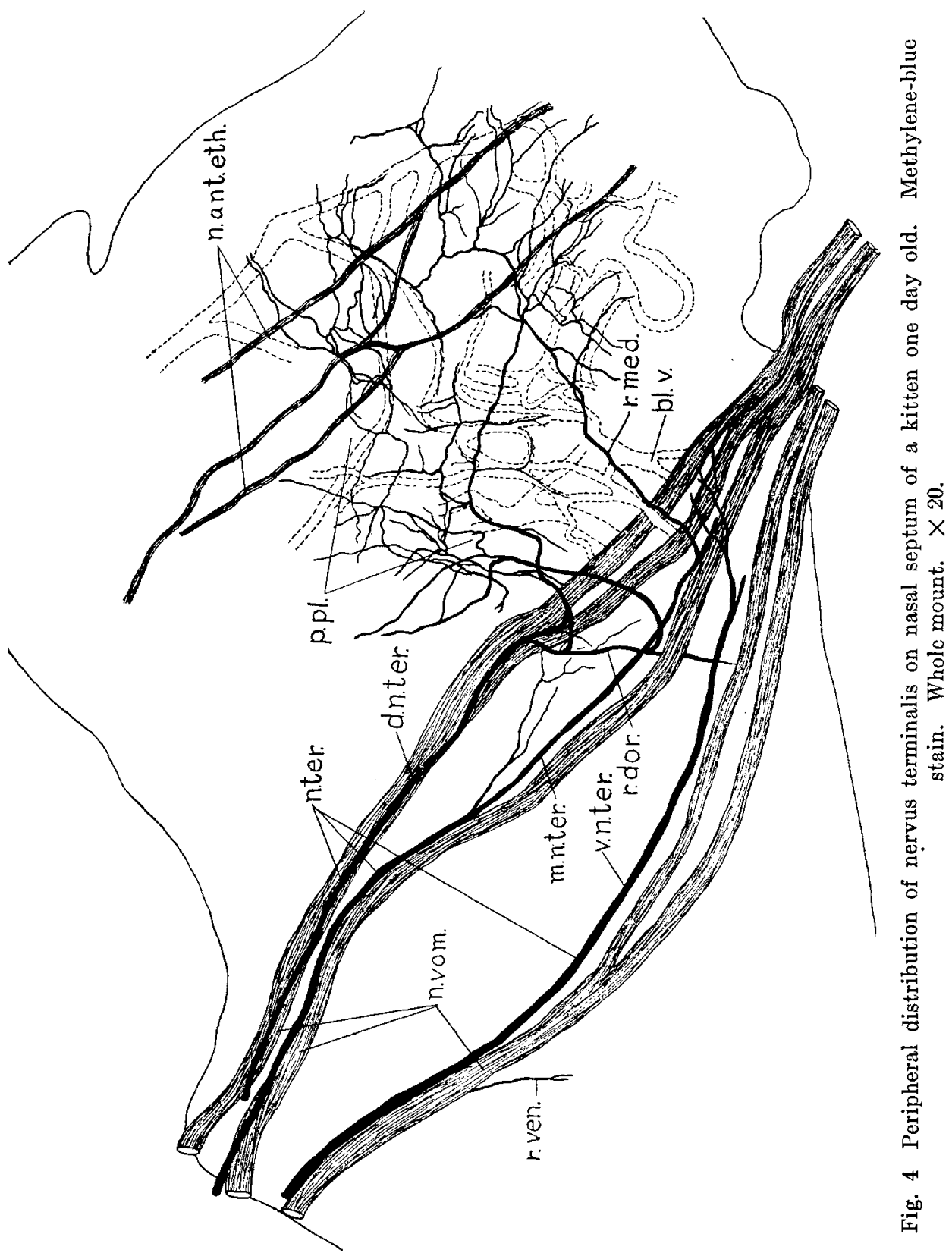


coursed toward that part of the mucosa which lay dorsal to the vomeronasal bundles, where the greater part of the plexus is located. Examination of the figure indicates that many of the nerve strands follow quite closely the paths of the blood-vessels represented by broken lines. Owing to the complexity of the vascular network, only the larger of these vessels were seen clearly enough in the preparations to make it possible to trace their courses. No ganglion cells or small ganglia were seen, but this was laid to the peculiarity of the stain. Silver and Weigert preparations revealed the presence of such cells in the nasal septum, but in much smaller numbers than are indicated in the rabbit by Huber and Guild ('13) or in the human by Brookover ('17). The ganglion clusters are, however, very numerous intracranially, especially on the mesial sides of the olfactory bulb.

While it seems likely that most of the plexus formed by the nervus terminalis on the nasal septum was seen, it is doubtless true that the rostral part of the septum, which unfortunately did not take the stain, also contains a continuation of this plexus. Pyridin-silver preparations indicate this beyond question in the cat, and it has been shown to be true in the rabbit by Huber and Guild, and in the human by Brookover, in the papers above cited.

The observations of the olfactory region of the mucosa are more dubious. In the methylene-blue preparations, the region in which olfactory fibers were present was stained a diffuse dark blue-green, which made it impossible to see any portion of the plexus if it were present. The pyridin-silver material shows occasional fibers in this region which may belong to the nervus terminalis, but this cannot be stated with any degree of certainty. It is possible that they are fibers from the anterior ethmoidal nerve, the main trunk of which lies in close proximity to many of the fibers found.

So far as the methylene-blue material indicates, there is no connection of the nasal plexus of the terminalis with either the anterior ethmoidal or the nasopalatine branches of the trigeminal nerve. The silver preparations, however, showed such a confusion of trigeminal and terminalis fibers in the rostral end 
of the septum that it seems certain that there is some commingling of fibers from the nasopalatine nerve in the terminalis plexus. This was also indicated, although somewhat less clearly, in Weigert preparations. The Weigert material showed very clearly that fibers from the anterior ethmoidal nerve take some

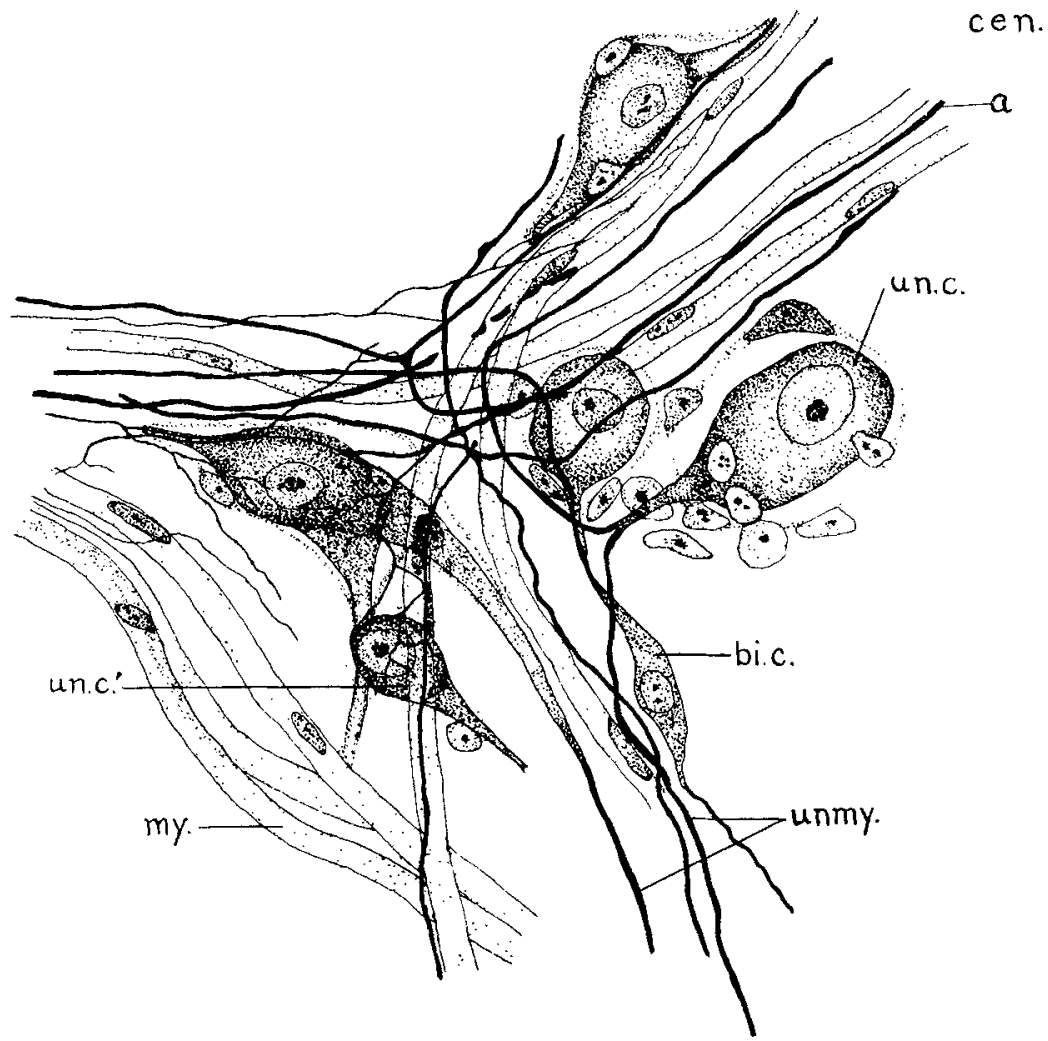

Fig. 5 A small cluster of cells slightly posterior and ventral to the ganglion (gn.) of figure 3, illustrating some of the types of ganglion cells, together with myelinated and unmyelinated fibers. Pyridin-silver technique. $\times 825$.

part in the formation of the peripheral plexus of the nervus terminalis. As shown in figure 22, which represents a portion of this plexus in a kitten one day old, a few myelinated fibers are present. Some of these were traced into a strand of the anterior ethmoidal nerve, which lay in close proximity to the 
portion of the plexus figured. This nerve shows development of the myelin sheaths, while the intracranial portion of the nervus terminalis of this specimen (fig. 23) gave no indication of myelin sheaths as brought out by the Weigert treatment. It does not seem likely that such sheaths would be formed in the peripheral portion of the nerve at an earlier date than they are formed in the part of the nerve nearer the brain. It is therefore assumed that they are fibers belonging to the already myelinated anterior ethmoidal nerve.

So far as this material indicates, the central roots of the terminalis, which are easily followed in the sections to their points

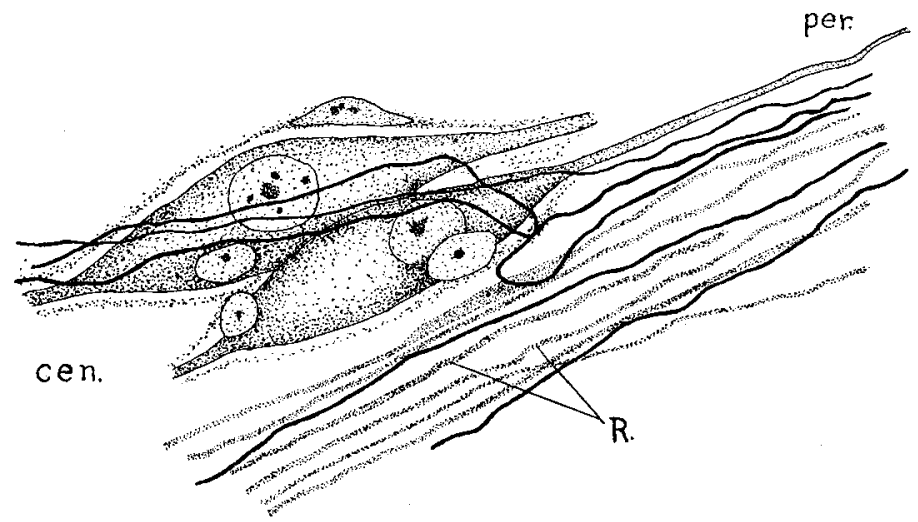

Fig. 6 Two bipolar cells and some of the nerve fibers from periphery of main ganglion (fig. $3, g n$.) of the nervus terminalis in kitten of two weeks. Pyridinsilver technique. $\times 1266$.

of entrance into the brain, are composed entirely of unmyelinated fibers. In kittens of two weeks, myelinated fibers are found in the intracranial plexus, although in these also no clear evidence of such fibers was found among the strands which enter the brain.

To avoid as far as possible the entrance of fibers from the fifth nerve as a factor, the greater part of the histological studies to be described was confined to the intracranial plexus and ganglia of the terminalis.

Histological. The plexiform character of the nerve in the cat, together with the structure of the ganglion cells to be described 
in the mule, and the relation of the nerve to the adjacent bloodvessels shown in cat, mule, and beef, suggested strongly that the nervus terminalis is composed, at least in part, of sympathetic fibers. There remains the possibility, which could not be adequately tested in the available equine or bovine material, that there may be a general or special sensory component, in addition to the motor and sensory sympathetic fibers which were found. It was accordingly deemed advisable to make as thorough a study of the terminalis ganglia and of the fibers connected with them in the cat as the material available would. permit.

The fact that the nerve is situated in a position so difficult of access, together with its small size, and the further circumstance of its relation to the cribriform plate, made necessary a technique permitting of decalcification, so that nerve and ganglia might be studied in situ. For this reason, chiefly, the pyridin-silver method, as previously described, was employed.

There was considerable variation in different parts of the same section in the intensity and clearness of the impregnation. It was also found that, in general, the cells of the smaller ganglionic clusters were much better differentiated from the background than were those in the more crowded larger ganglia. Because of this fact the majority of the cells figured are from the small clusters of cells, but for comparison, considerable attention was paid to the large ganglionic mass (figs. 1, 2 and 3, gn.) which appears to correspond with the 'ganglion terminale' of authors.

Types of ganglion cells. Figure 5 represents a typical small ganglionic mass which had its position in the meninges covering the mesial side of the olfactory bulb. It lay slightly caudad to the ganglion terminale and a little more ventrally. This cluster was similar to numerous others scattered throughout the plexus. Such clusters of cells are usually situated at the meeting point of several small strands of fibers which converge from various directions. The group of cells figured represents only a portion of this particular ganglionic mass. The remaining portion was to be seen in the next section of the series. 
It will be noted that both myelinated (my.) and unmyelinated (unmy.) fibers are present. The axis cylinders of the myelinated fibers were stained a darker orange color than were the myelin sheaths surrounding them. The processes of the unmyelinated fibers were quite black and stood out distinctly. One of the latter $(a)$, which comes from the direction of the central connection of the nerve, divides into two smaller fibers which in turn subdivide into terminations with small varicosities, and which form simple pericellular baskets on two of the nerve cells shown.

Several classifications, both of ganglion cells and of sympathetic cells, have been made by investigators, notably by Cajal ('05) Dogiel ('08), and Ranson ('12) for the former; and by Cajal ('05), Carpenter and Conel ('14), Dogiel ('96), Michailow ('11), and others for the latter type. There is considerable individual variation among the ganglion cells observed in the terminalis clusters, and they come within one or the other of these classifications. Still, for purposes of description it is convenient to designate the types observed according to the number of processes they possess as unipolar, bipolar, and multipolar. A few binucleated cells were seen in the cat, but aside from the number of nuclei, they resembled the other cells of the several varieties and will not be treated separately.

(a) Unipolar cells. Most of the unipolar cells observed resemble those usually considered characteristic of the spinal ganglia. The body of the cell (figs. 5, 10, 18) is ovoid or spherical, with a rather large nucleus. The single process, which usually stained brown near the cell body, becomes darker as it assumes a smaller diameter in its course away from the perikaryon. In those cases in which it was possible to follow it for any distance, it divides into two processes, one directed in the general direction of the central connection of the nerve, the other peripherally as respects this connection. No marked difference in size of these two divisions was noted, although that which appeared to be the central process was usually slightly smaller in diameter. It must be understood that only the general direction of the course of these fibers is indicated, because of the various directions different strands of the plexus assumed. 
While myelinated fibers were present in the same bundles which included processes from the unipolar cells, in no case was a myelin sheath found in connection with processes from such cells.

Three distinct sizes of unipolar cells were observed. The predominating size is represented in figure 5 (un.c.), which also

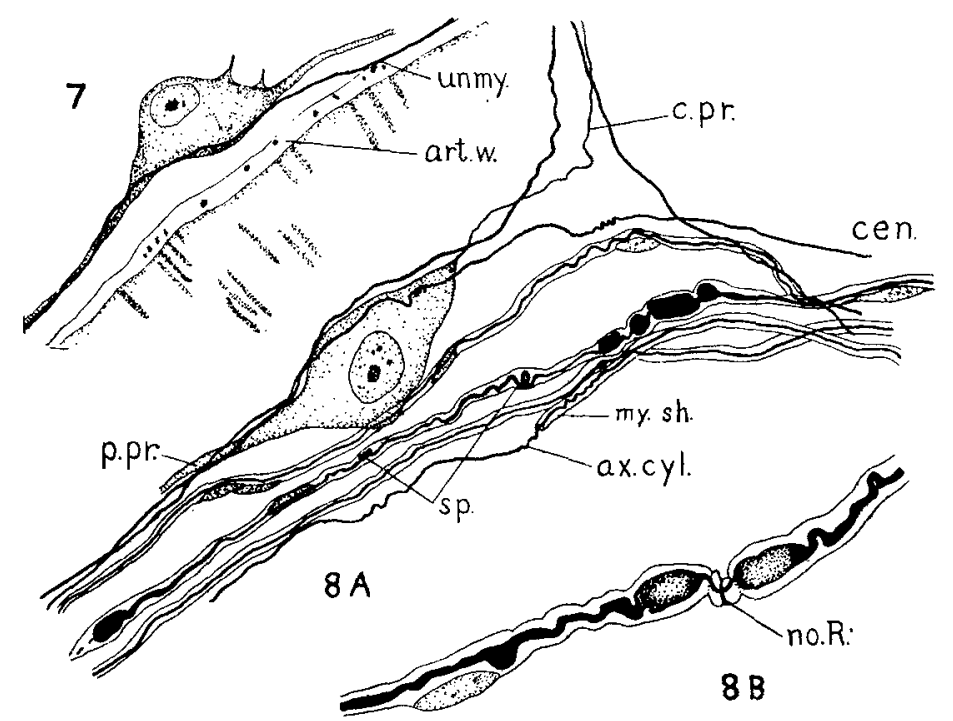

Fig. 7 Bipolar cell and accompanying unnyelinated fiber on the wall of a blood-vessel between the cerebral hemisphere and the olfactory bulb. Kitten two weeks old. Pyridin-silver teehnique. $\times 450$.

Fig. 8A Characteristic small bundle of myelinated and unmyelinated fibers, with a single bipolar cell in its course. Fig. 8B Portion of a myelinated fiber more highly magnified, showing a node of Ranvier, and some large varicosities. Both from kitten of two weeks. Pyridin-silver technique. Figure $8 \mathrm{~A}, \times 660$; figure $8 \mathrm{~B}, \times 950$.

indicates very clearly the bifurcation of the single process of the cell. Figure 5 (un.c'.) also shows one of the smallest of the unipolar cells seen. The process of this cell could not be followed for any great distance and no bifurcation was seen. The process was directed peripherally. Attention may again be directed to the pericellular basket surrounding this cell. The relation of the cell to the nerve fiber of which this basket is the termination, 
together with the peripherally directed process of the cell, suggests that it pertains to the sympathetic system. Its small size favors this interpretation.

The largest unipolar cell observed (fig. 10) was also the only one of this type found which was binucleated. The process was of large diameter and did not stain so dark as did the majority of fibers. It was not possible to follow it beyond its point of entrance into the bundle of smaller black fibers of which it became a part. The large size, both of cell and of cell process, resembles somewhat the large unipolar cells found by Carpenter ('12) in the ciliary ganglion of the sheep.

Unipolar cells were not numerous and were found only in the smaller ganglia. Whether their presence in the larger ganglia was hidden by the crowded condition of these could not be determined. It seems, however, that the latter are composed principally of multipolar cells, with fairly numerous bipolar cells near their peripheries.

(b) Bipolar cells. Cells of this type are quite numerous, both in the smaller ganglia and in the larger ones. A number of such cells isolated from other nerve cells were also found. Figure 6 represents two typical bipolar cells from the periphery of the largest ganglion (fig. 3, gn.) of the left nervus terminalis of a kitten of two weeks. The processes of these, which are of large size, took only a brownish tinge from the impregnation. A few fibers of small size which stained black were present in the immediate neighborhood of these cells and are indicated in the figure, as are also some large unmyelinated fibers. These are doubtless fibers of similar bipolar cells. A few relatively small bipolar cells were found, one of which is shown in figure 5 (bi.c.). The processes of these were quite slender and stained black. They were followed for some distance, but no conclusive evidence as to their terminations was obtained.

The isolated bipolar cells above noted were found in the course of small strands of fibers, between the nodal points where several such strands converge (fig. 8). A few were found on the walls of blood-vessels or near them. One of these is illustrated in figure 7 , in which also is shown an unmyelinated fiber of small size 

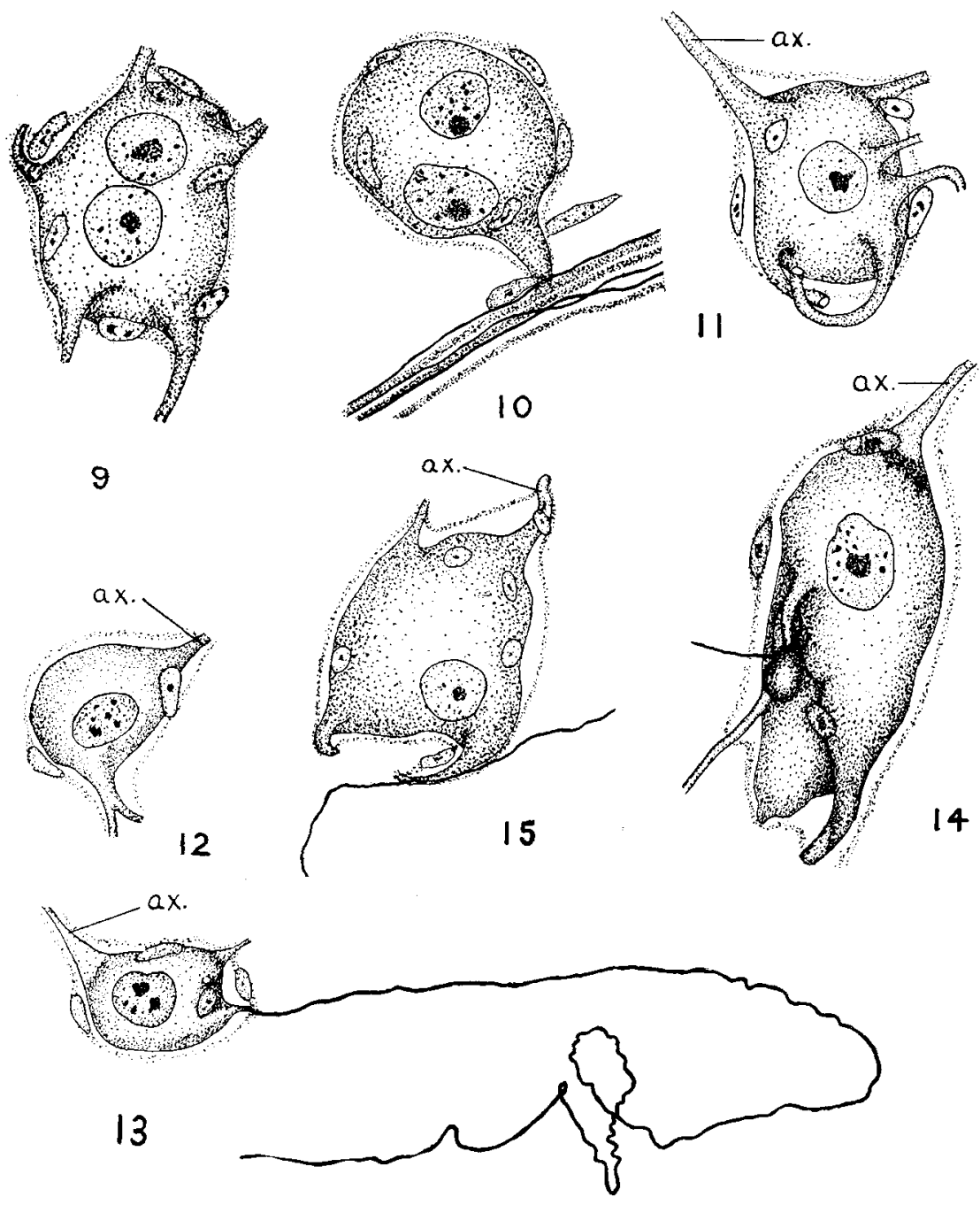

Figs. 9 to 15 Ganglion cells from intracranial clusters of nervus terminalis of kitten two weeks old. Figures 12 and 13 were drawn from cells which lay in the trunk of the nerve between its points of entrance into the brain wall and the main portion of the plexus; figures 14 and 15 were drawn from cells which lay near the center of the main ganglion $(g n$.$) and the other figures were drawn from$ cells in various portions of the plexus. Figures 9, 10,11, and 14 magnified 990 times; figures 12 and 13 magnified 1020 times, and figure 15 magnified 675 times. Pyridin-silver technique. 
which runs parallel with the processes of the cell. The position of this cell was well within the crevice between the olfactory bulb and the cerebral hemisphere, on the wall of a blood-vessel which passes between the bulb and the hemisphere. The processes of the cell were stained rather lightly by the silver and it was not possible to follow them far. Their course so far as visible was parallel with the wall of the artery. Two slender processes may be seen to issue from the cell, in addition to the polar processes of much larger size. Because of these slender off shoots the cell should possibly be classed with those of multipolar type, but it is included with the bipolar cells because of its greater similarity in other respects.

In figure $8 \mathrm{~A}$ is shown a cell whose position was on the medial surface of the olfactory bulb, posterior and ventral to the main ganglion of the terminalis. The larger process ( $p . p r$.$) is directed$ toward the ganglion, while the very slender process from the opposite pole of the cell is turned in the general direction of the central connection of the nerve with the brain, although the group of three fibers of which it forms one, turns at right angles to the principal axis of the terminalis plexus. This process was followed for some distance, but it was lost in the plexus centripetally.

(c) Multipolar cells. The multipolar type of cell predominates in the ganglia. These cells vary in size from the relatively small ones shown in figure 16, to the large cells drawn to the same scale represented in figures 9,11 and 17 . The number of processes varies. The cells illustrated in figures 12 and 13, which were found on the main trunk of the nerve, show but three processes. The majority of multipolar cells included in the small ganglia have at least five offshoots. Typical examples of such cells are shown in figures 11 and 16 . The axone could not always be determined with certainty, but in the cells shown in figurea $11,12,14$, and 15 the process marked $a x$. appeared to be the axone. In each of these cases it was directed centripetally. That which appeared to be the axone of the cell shown in figure $13(a x$.) was directed peripherally. This cell lay in the course of the main trunk of the nerve. 

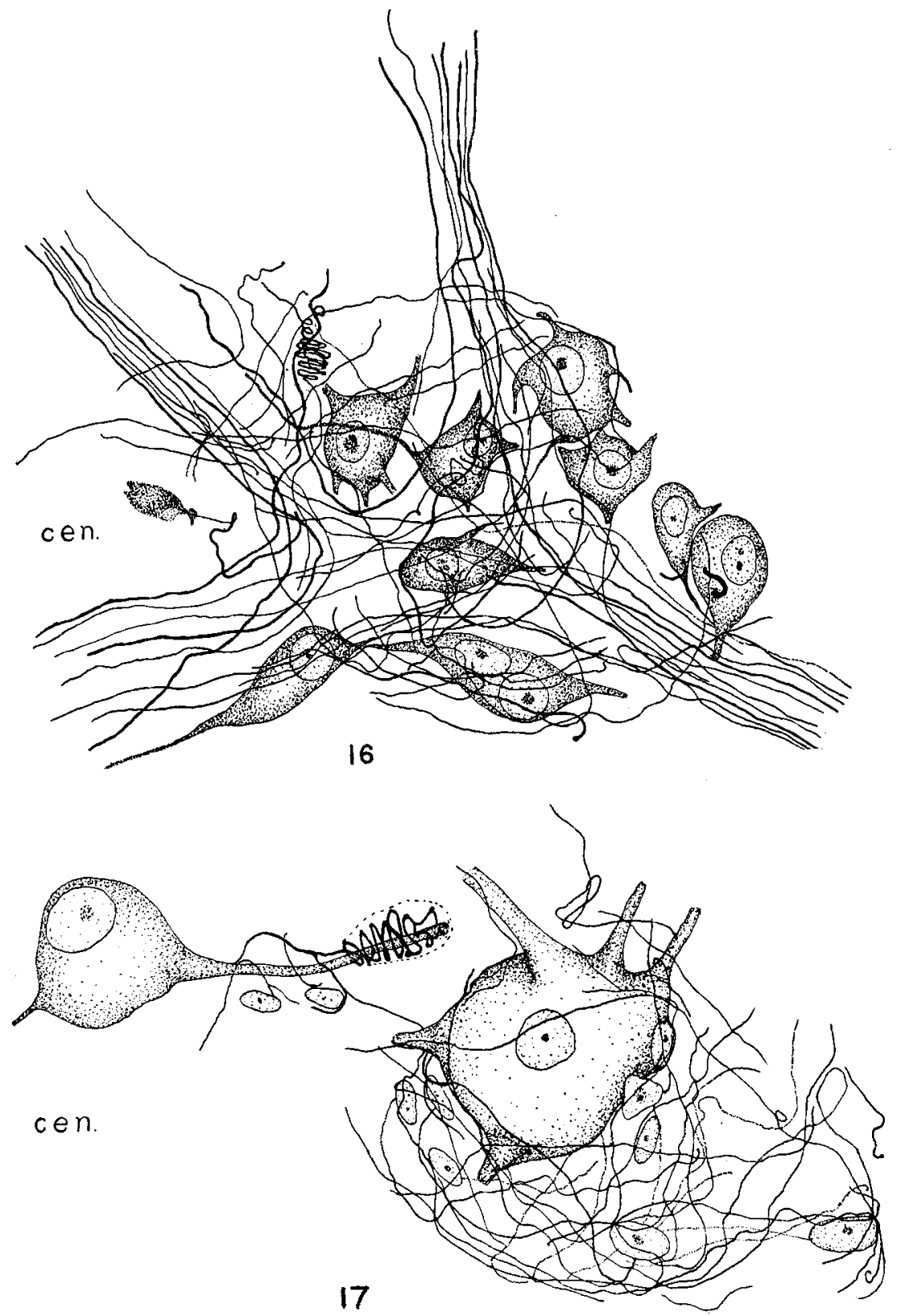

Fig. 16 Small ganglionic cluster and intercellular network from portion of intracranial network of nervus terminalis near lower posterior border of olfactory bulb. Kitten two weeks old. Pyridin-silver technique. $\times 990$.

Fig. 17 Large multipolar cell with extracapsular network from intracranial plexus of nervus terminalis of kitten two weeks old. Pyridin-silver technique. $\times 990$. 
Very few binucleated cells of the multipolar type were observed. These, as illustrated by the one represented in figure 9 , were similar in every other respect to other multipolar cells.

Fibers and fiber networks. A few of the individual cells were surrounded by a reticulum of delicate fibers which suggest an extracapsular network (fig. 17). The capsule itself was not easy to see in such cares, but the position of the capsule nuclei within the network seems to justify the interpretation given to these reticula. In the example illustrated, a small number of threads extend from the region of a neighboring bipolar cell and take part in the formation of the pericellular plexus described. The main fiber from which these threads have their origin, runs parallel to the larger process of the bipolar cell, and appears to terminate in a spiral (fig. 17) about this process. The fibers forming this network are intertwined in the most confusing manner in every direction. They are of very small size.

Intercellular networks also were found in those parts of the preparations where the impregnation was most favorable. A peculiarity of the impregnation revealed itself in the fact that those parts of the sections which showed the fibers most clearly did not serve so well to differentiate the outlines of the cell bodies and of the large processes from the perikaryon.

The intercellular networks were found in every case at nodal points where a number of fiber strands converge. Usually the ganglion cells enclosed by such a network were of small size, but occasionally a larger cell was also included. In the example illustrated (fig. 16), which was situated near the lower margin of the posterior portion of the olfactory bulb, four strands of fibers converge about a small group of cells. Many of the individual threads may be followed from one strand through the cell cluster and into one of the other converging strands, without any apparent connection with the cells. The majority of fibers were lost in the network. A few may be seen to connect with nerve cells of the cluster.

This intercellular network resembles to a considerable degree structures of a similar nature found by Dogiel ('95) in the digestive tract of the dog. It bears an even more striking resem- 


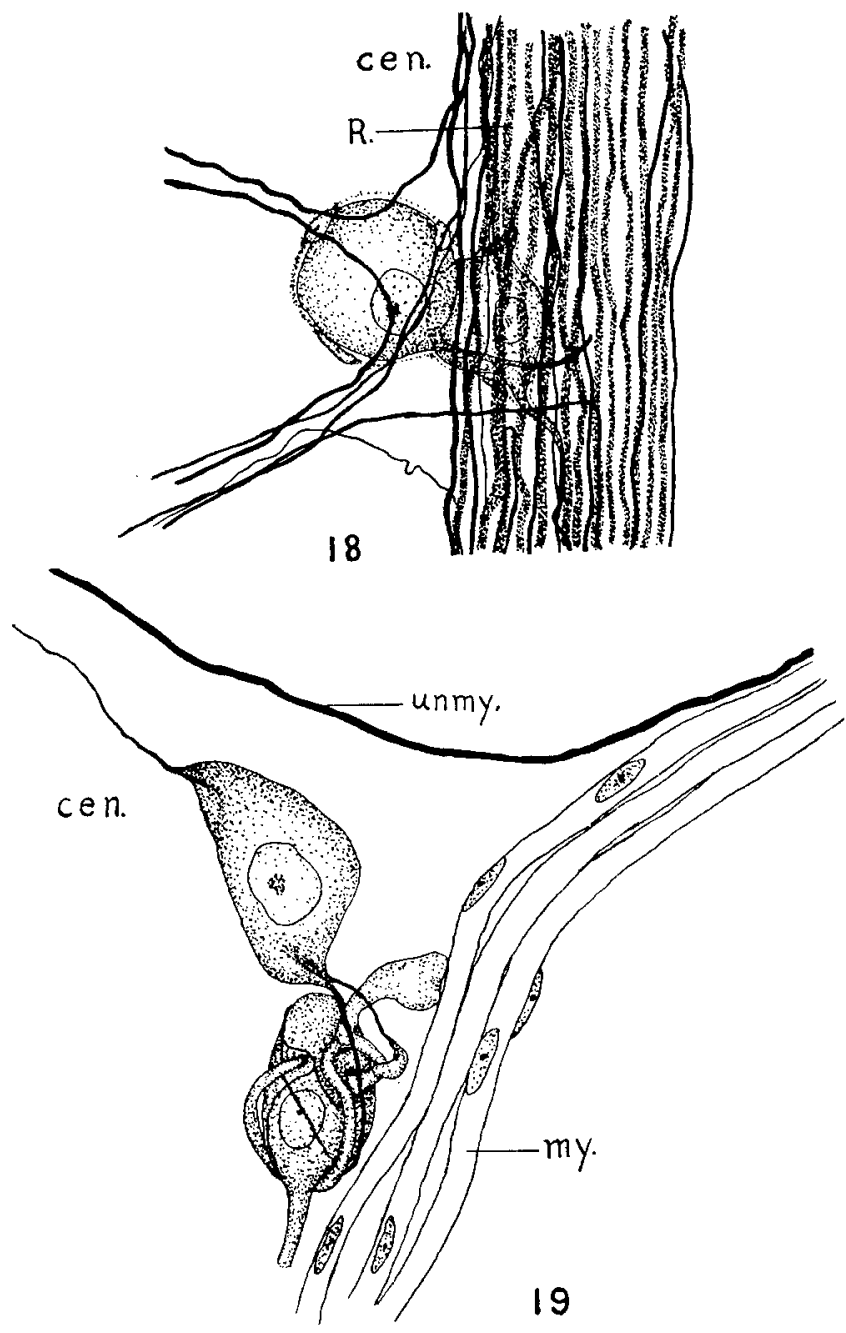

Fig. 18 Bundle of fibers with two cells in its course, and showing the characteristic method by which small strands of fibers leave the larger bundles. Kitten two weeks old. Pyridin-silver technique. $\times 675$.

Fig. 19 A somewhat isolated strand of myelinated fibers and a single unmye. linated thread of relatively large size as compared with the centrally directed process of the nerve cell shown. Kitten two wceks old. Pyridin-silver technique. $\times 990$. 
blance to networks found by Ranson and Billingsley ('18) in the cervical ganglion of the dog.

An attempt was made to analyze the various strands of the plexus, in order to determine, if possible, the types of component nerve fibers. As previously stated, both myelinated and unmyelinated fibers are present. Of the latter type, both varieties, namely, fibers of Remak and naked filaments, are abundant. While for short stretches some of the strands appear to be composed exclusively of one type or the other (figs. 5, 6, 8, 19), the rule is mixed strands. The fibers of Remak predominate as to number when the entire plexus is considered. They are particularly numerous near the main ganglion, and appear to include the majority of fibers which enter this ganglion.

In figure 20 are shown two converging strands consisting principally of Remak's fibers, which approach this ganglionic mass. The bundle resulting from their union was one of the most compact of the entire plexus. Naked filaments of several sizes are also included in it. One of the most slender of these $(f)$ is seen to approach the nerve cell represented in the figure and to follow what appeared to be the axone of the cell, to end on the perikaryon in a simple pericellular termination. A similar strand, but with fewer naked fibers, is shown in figure 21, which was drawn from near the ventral border of the posterior part of the olfactory bulb. This bundle of fibers runs parallel with one of the arteries of this region. An offshoot ( $\mathrm{ram}$.) consisting of four or five threads leaves the main strand and passes to the wall of a branch of the artery.

Two fibers which show no neurilemma sheath leave the strand to pass to the wall of the main artery. These strands so closely resemble others, the terminations of which are described below, that it seems certain that they represent fibers which ramify to form the type of nerve-endings shown in figures 24 to 29 . Whether or not the fibers of Remak terminate in the sensory endings represented in figures 28 and 29 could not be determined with certainty. It seems unlikely, in view of the fact that the fibers leading to the sensory terminations show myelin sheaths near their endings. The naked filaments show considerable 
variation in size, the finer fibers greatly outnumbering those of coarser diameter.

The myelinated fibers are relatively few in number. They usually occur in strands of three to five filaments, accompanied

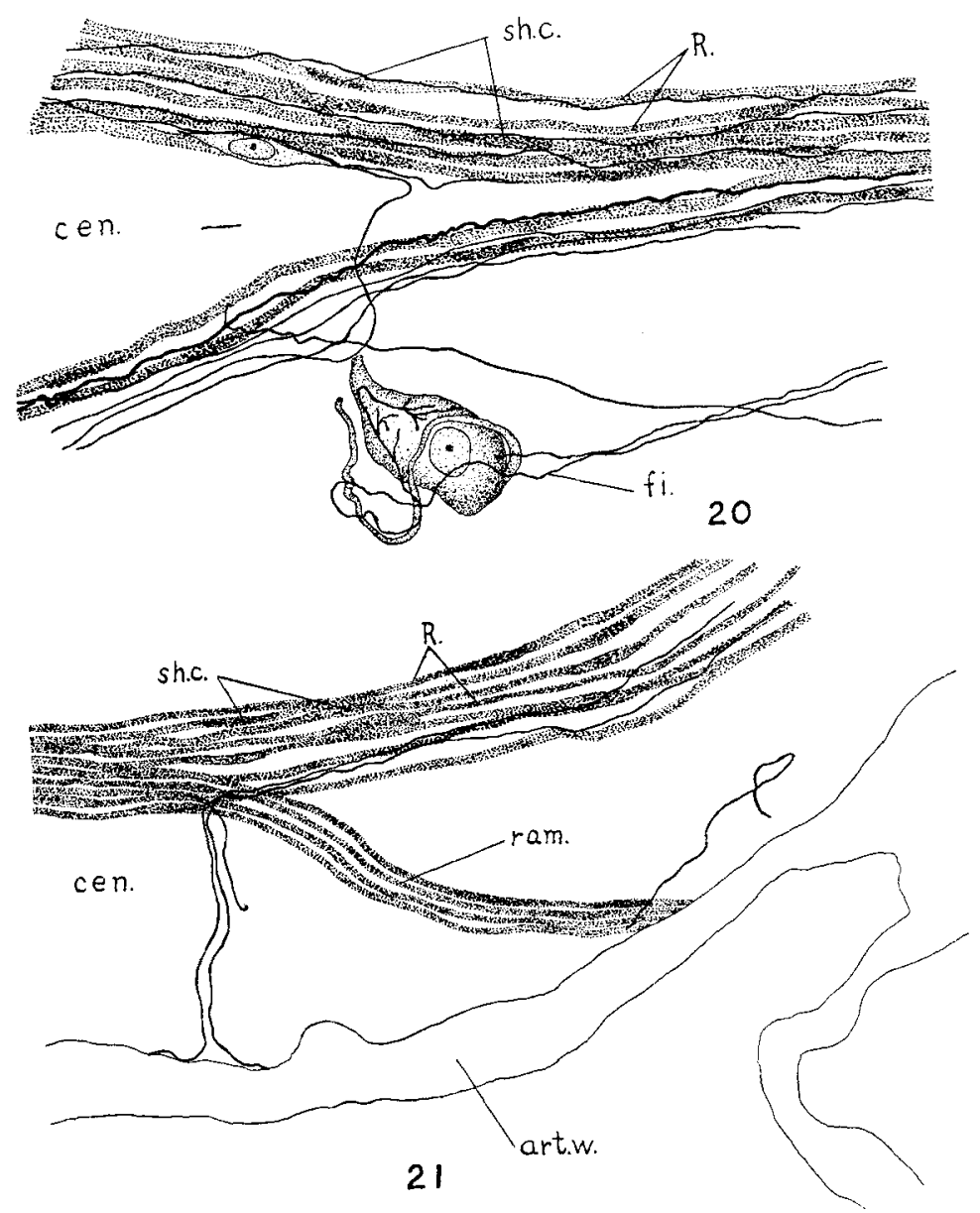

Fig. 20 A bundle of fibers from near the dorsal margin of the olfactory bulb, caudad to the main ganglionic mass. The strand divides centrally. Kitten two weeks old. Pyridin-silver technique. $\times 600$.

Fig. 21 A bundle of fibers from near ventral margin of olfactory bulb in about the same vertical plane as figure 20, showing relation of some of the fibers to a blood-vessel. Kitten two weeks old, Pyridin-silver technique. $\times 600$. 
by naked threads. In some cases these naked filaments represent fibers which have lost their myelin sheaths (fig. 8A, ax. $c y l$.). Many of them show very large varicosities (fig. 8, $A$ and B), the most pronounced of which are often found near the nodes of Ranvier. These varicosities appear to have been produced by unequal shrinkage of the axis cylinder, probably during the process of fixation of the tissue. At other points, as shown in the figures, the cylinders are extremely attenuated. Some show spiral formations of the axis cylinder within the myelin sheath (fig. $8 A, s p$.), In diameter the intracranial myelinated fibers varied from $1.5 \mu$ to $2.6 \mu$.

In the septal plexus of the terminalis, myelinated fibers are found intermingled with the unmyelinated threads (fig. 22). As previously stated, these belong, in part at least, to the trigeminus. It is possible that the myelinated fibers of the intracranial plexus are related to those found in the septal plexus, and may therefore be trigeminal in origin. This does not seem likely, but can only be adequately tested by degeneration experiments, which the writer hopes to perform.

The roots which enter the brain, in both of the extra-uterine stages of growth of the cat in which this point was examined, appear to be composed exclusively of unmyelinated threads (fig. 23). Fibers of Remak predominate, but a few naked filaments are mingled with them.

Nerve terminations. There are present in the cat two kinds of nerve terminations in the walls of the cerebral :blood-vessels, which are connected with fibers from the nervus terminalis. A third type consisting of free endings in the epithelium of the nasal septum appears also to be related to this nerve.

The nerve terminations in the walls of the anterior cerebral artery and its branches, for convenience of description, will be designated as type I and type II.

Type I (figs. 24 to 27 ) consists of delicate varicosed fibers which penetrate the muscular walls of the blood-vessels from the nervous plexus surrounding these vessels. At varying depths in the muscular layer, the fibers which penetrate the arterial coat ramify into very fine arborizations which pass between the smooth 
muscle cells and end on the latter. The nerve fibers which end in this manner are in every case unmyelinated. They show very slight typical varicosities. The twigs of the terminations are

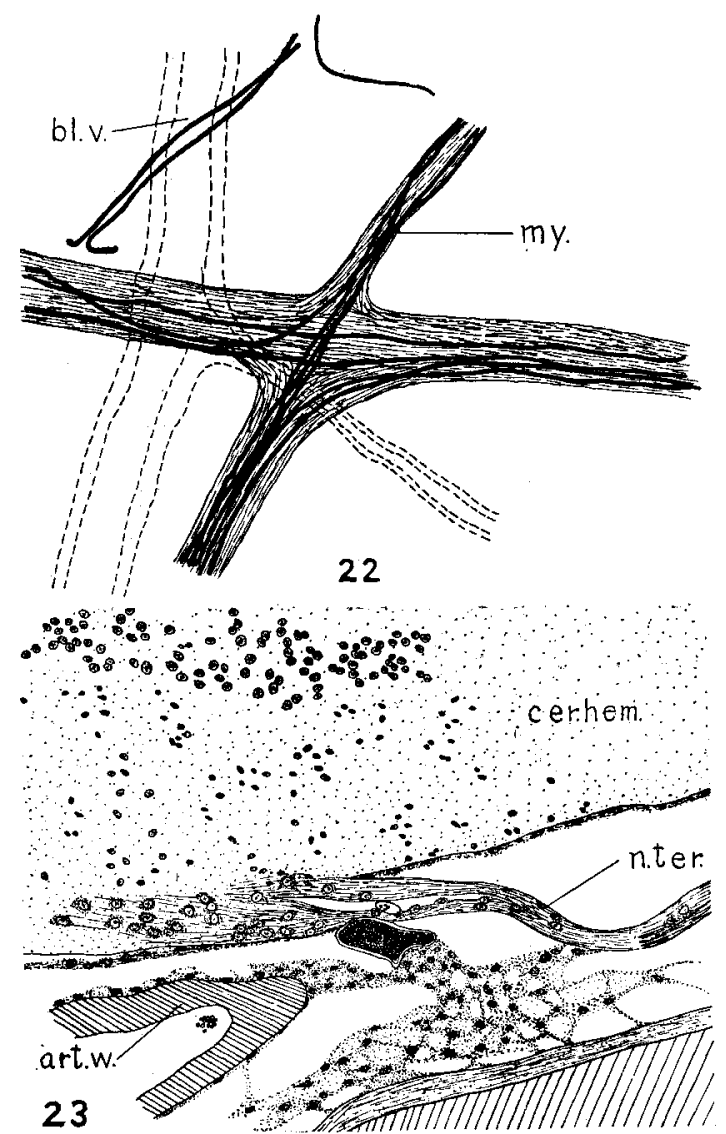

Fig. 22 Portion of septal plexus showing the presence of myelinated fibers. Midway between principal vomeronasal foramen and rostral end of nasal septum. Kitten one day old. Weigert technique. $\times 230$.

Fig. 23 Central roots of nervus terminalis at point of entrance into brain wall. Kitten one day old. Weigert technique. $\times 75$.

also varicosed. It will be noted from the figures that the manner of distribution of these terminations varies considerably. Those represented in figures 25 and 27 end in relatively short, 
stout twigs. Others (figs. 24 and 26) have long, very delicate branches, which sometimes continue their course parallel with the plane of the fibers from which they spring, sometimes di-

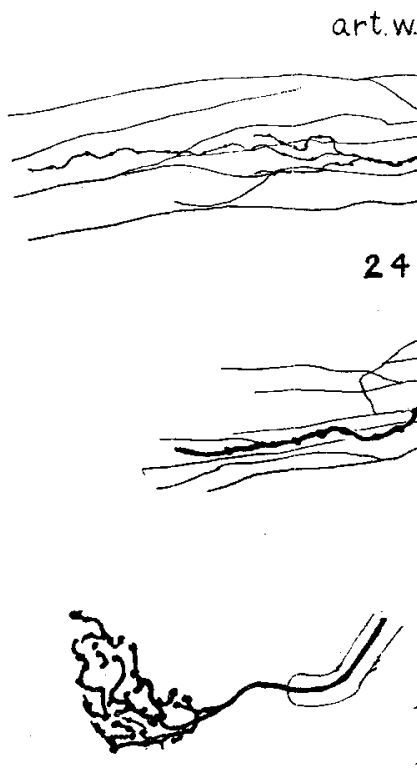

29

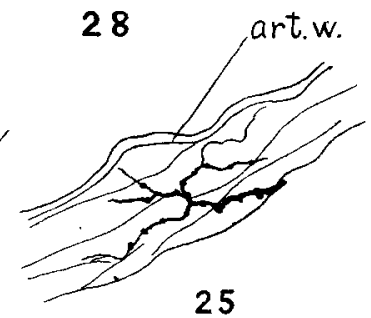

25

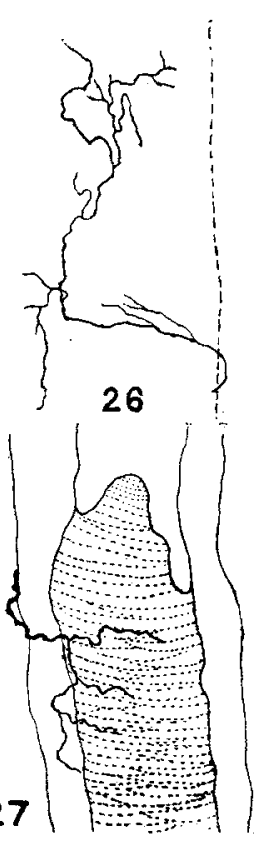

Fig. 24. Motor nerve termination from muscular coat of anterior cerebral artery of kitten two weeks old. Gold-chloride technique. $\times 1020$.

Fig. 25 Motor nerve termination from branch of anterior cerebral artery of kitten two weeks old. Gold-chloride technique. $\times 1020$.

Fig. 26 Motor nerve termination from one of the vessels on the mesial surface of the olfactory bulb (in pia mater) of kitten two weeks old. Pyridin-silver technique. $\times 1425$.

Fig. 27 Motor nerve termination from one of the blood-vessels of the nasal septum of kitten one day old. Pyridin-silver technique. $\times 1425$.

Fig. 28 Sensory nerve termination from anterior cerebral artery of kitten two weeks old. Gold-chloride method. $\times 1020$.

Fig. 29 Sensory nerve termination from a small vessel in the meninges near the olfactory bulb of kitten two weeks old. Pyridin-silver method. $\times 1425$.

verge from it at various angles. These terminations appear to be similar to those found by Huber ('99) in the cat, and considered by him to be motor endings. 
The terminations represented in figures 24 and 25 were stained by the gold-chloride method. Those shown in figures 26 and 27 are from pyridin-silver preparations. Similar endings were also found by the molybdenum methylene-blue process, in the anterior cerebral artery and its branches, from which vessels all of the preparations were made.

The type II endings are strikingly different in appearance from those of type I. As shown in figures 28 and 29 , the terminations are by somewhat spindle-shaped structures, composed of short, thick branches from the main fiber. These rami end with terminal knobs. In the gold-chloride preparations (fig. 28) a spindle-shaped clear space appears to be enclosed by the short processes which are derived from the nerve fiber. In the silver material no such clear space is evident, although the general contour of the termination is the same as in the gold preparations. The pyridin-silver slides showed the presence of delicate myelin sheaths on the fibers leading to these terminations. Such sheaths are not clearly evident in the gold chloride material of the cat, although similarly prepared slides of the corresponding bloodvessels of the beef indicate their presence in that animal. No capsules are present around these terminations in any of the animals in which they were examined. The methylene-blue staining did not clearly demonstrate this type of endings, although suggestions of them were visible by this method also.

In general appearance these end-organs resemble to some extent the corpuscles of Ruffini, but are much smaller. Both in shape, however, and in the absence of a capsule, they bear a stronger similarity to a type of sensory ending found by Dogiel in the heart of the cat (Dogiel, '96, fig. 2, D). Smirnow describes terminations of somewhat similar appearance in the atrial endocardium of the cat (Smirnow, '95, fig. 6), and Michailow ('08) has also described non-capsulated sensory terminations in the myocardium.

In the anterior cerebral artery and its branches of the cat and of the beef, they lie not in the loose connective tissue, but scattered at various levels in the muscular coat itself. 
So far as the writer is aware, similar structures have not heretofore been described in the walls of the cerebral bloodvessels. Huber ('99) noted myelinated fibers along the walls of the cerebral arteries of the cat, and considered them to be sen-
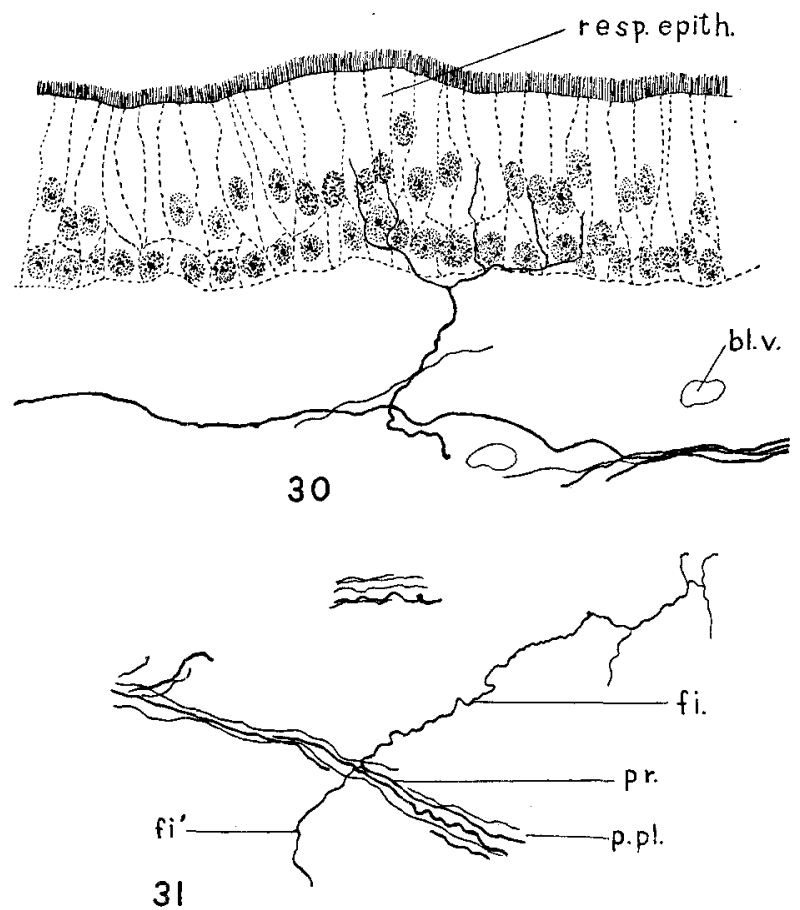

Fig. 30 Free nerve terminations in respiratory portion of nasal mucosa of kitten one day old, also a portion of the nervous plexus. Pyridin-silver technique. $\times 600$.

Fig. 31 Portion of the septal plexus of the nervus terminalis of kitten one day old, showing one of the fibers bifurcated and ramifying into slender twigs which appear to have been cut off at their ends. Pyridin-silver technique. $X$ 600 .

sory as distinguished from the unmyelinated motor fibers which he found in company with them.

The compact form of this type of endings, differing to so marked a degree from the other type which has been described as motor, and closely resembling sensory terminations in other 
parts of the vascular system, seems to justify the assumption that they are sensory in function.

The third type of ending to which reference was made was found among the epithelial cells lining the mucosa of the nasal septum. These endings consist of very delicate arborizations which pass between the columnar cells of the epithelium and approach the surface of the membrane (fig. 30). They are terminal twigs of fibers which appear to be unmyelinated. These fibers, as shown in the figure, approach the epithelium in small strands of three or four fibers to spread out at its base, where the terminal threads which form the free end fibers are given off. No varicosities or end-knobs were seen.

Such terminations are present in both sensory and respiratory regions of the septal mucosa and in the epithelium of the vomeronasal organ. Similar endings, but with varicosities or endknobs, have been described and figured in these regions by von Brunn ('92), von Lenhossék ('92), Retzius ('92), Cajal ('94), Read ('08), and others. Most of these writers tend to ascribe them to the trigeminal nerve, although von Lenhossék suggests the possibility that they represent olfactory fibers whose cells of origin do not have the same position as others, but lie within the centripetal olfactory tract, enclosed in the course of the olfactory bundle.

Figure 31 represents what appears to be the centripetal continuation of a fiber which gives rise to free endings such as those just described. This figure was drawn from a section which lay just below the epithelium, in a sagittal series through the nasal septum. As shown in the figure, the fiber $(f)$ divides at its extremity into four slender twigs which appeared as if they had been cut near their tips. Centripetally this fiber unites with a similar one $\left(f^{\prime}\right)$. The nerve process of which these fibers are branches is part of a small bundle ( $p . p l$.) which forms a portion of the terminalis plexus of the nasal septum shown in figure 4 .

While the fibers which terminate in the manner indicated resemble in size and distribution those of the nervus terminalis, there remains the possibility that they are the continuation of the more delicate threads which are present in the nasopalatine 
and anterior ethmoidal branches of the trigeminal nerve. As already noted, there is a commingling of fibers of this nerve and of the terminalis, and fibers of the trigeminus enter the bundles which constitute the septal plexus of the terminalis. The intricacy of this plexus made it impossible to follow any individual fiber very far. Accordingly it was not possible to determine with certainty whether the free terminations of the septal mucosa are from terminalis fibers or from the trigeminal nerve.

Other fibers of larger size are also present in the mucosa. These terminate on or near the septal glands, and show varicosities on their finer twigs. They also enter into the plexus of the terminalis to some extent. They are given off from the fifth nerve. It is usually stated that the septal glands are innervated by the trigeminus, and these fibers appear to be the ones by which this is accomplished.

\section{The nervus terminalis of the beef}

The nervus terminalis of the beef, as shown in figure 32, lies median to the olfactory nerves, between the meninges and the ventral brain surface. Running parallel with it are branches of the anterior cerebral artery. In the specimen figured the greater portion of the left nerve is a compact bundle, while the right nerve is composed of several strands for the greater part of its length. In the numerous brains examined there was considerable variation in the relation of the different strands which by their union form the main nerve bundle. This variation was found not only when comparing one brain with another, but, as just indicated, on comparing the two nerves of the same specimen. In some cases the strands were independent up to a short distance from the forward margin of the hemispheres, in other cases the bundle was formed much further caudad.

For the greater part of its course the portion of the nerve present in the specimens was covered by the meningeal membranes. It emerges to the outer surface of the arachnoid coat at about the point where the cerebral hemispheres begin to curve upward. At this point the nerve was always compact in a single bundle. 
This bundle after emerging lay free on the surface of the arachnoid. The appearance of the free end indicated that it had been stretched and broken in removing the brain from the cranial cavity.

Several ganglionic swellings are visible, the largest one in the brain from which the figure was drawn, at the point (fig. 32, gn.) where the nerve crosses the artery. Just caudad to this ganglion, as more clearly shown in figure 33 , the bundle divides into two strands. A short distance rostral to this ganglionic

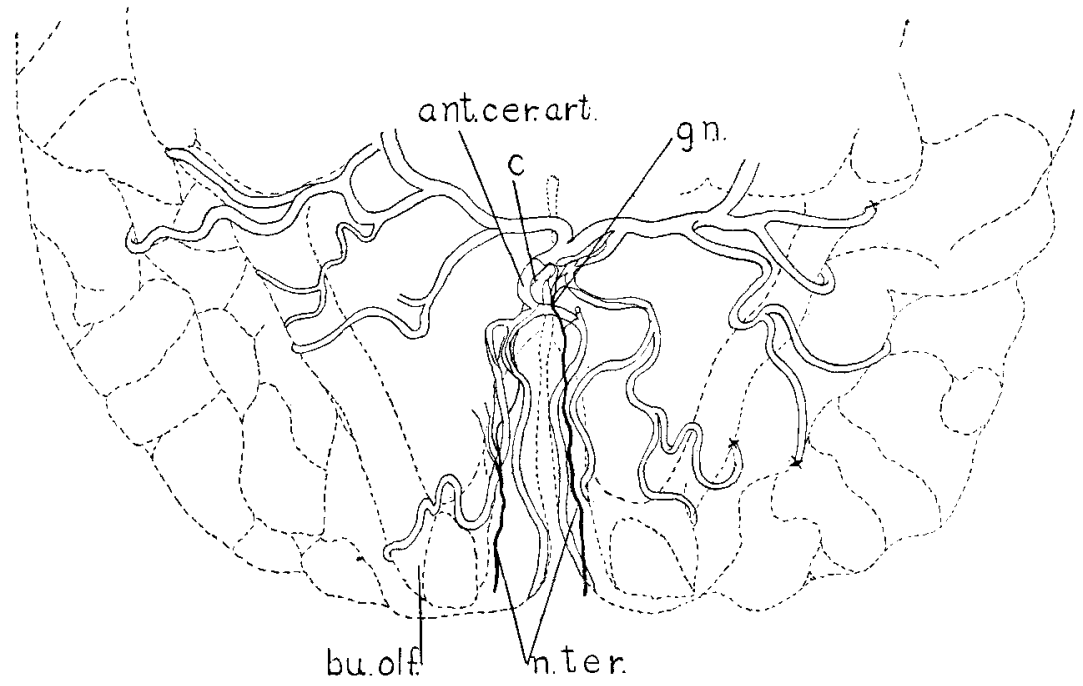

Fig. 32 Ventral view of anterior portion of the beef brain, showing the nervus terminalis and a portion of the anterior cerebral artery and some of its branches. Nerve strands traced along arteries to points marked $x$.

mass, a similar strand is given off from the main trunk. These strands follow the branches of the anterior cerebral artery, as indicated in figures 32 and 33, ramifying to the secondary branches of these vessels, and at intervals they give off fine twigs which penetrate into the muscular walls of the arteries.

Several of the strands were traced continuously to the points marked $x$ in figure 32, where the respective arteries dipped into the fissures. On the same brain, and on others, similar strands were found on all of the arteries examined in this region of the 


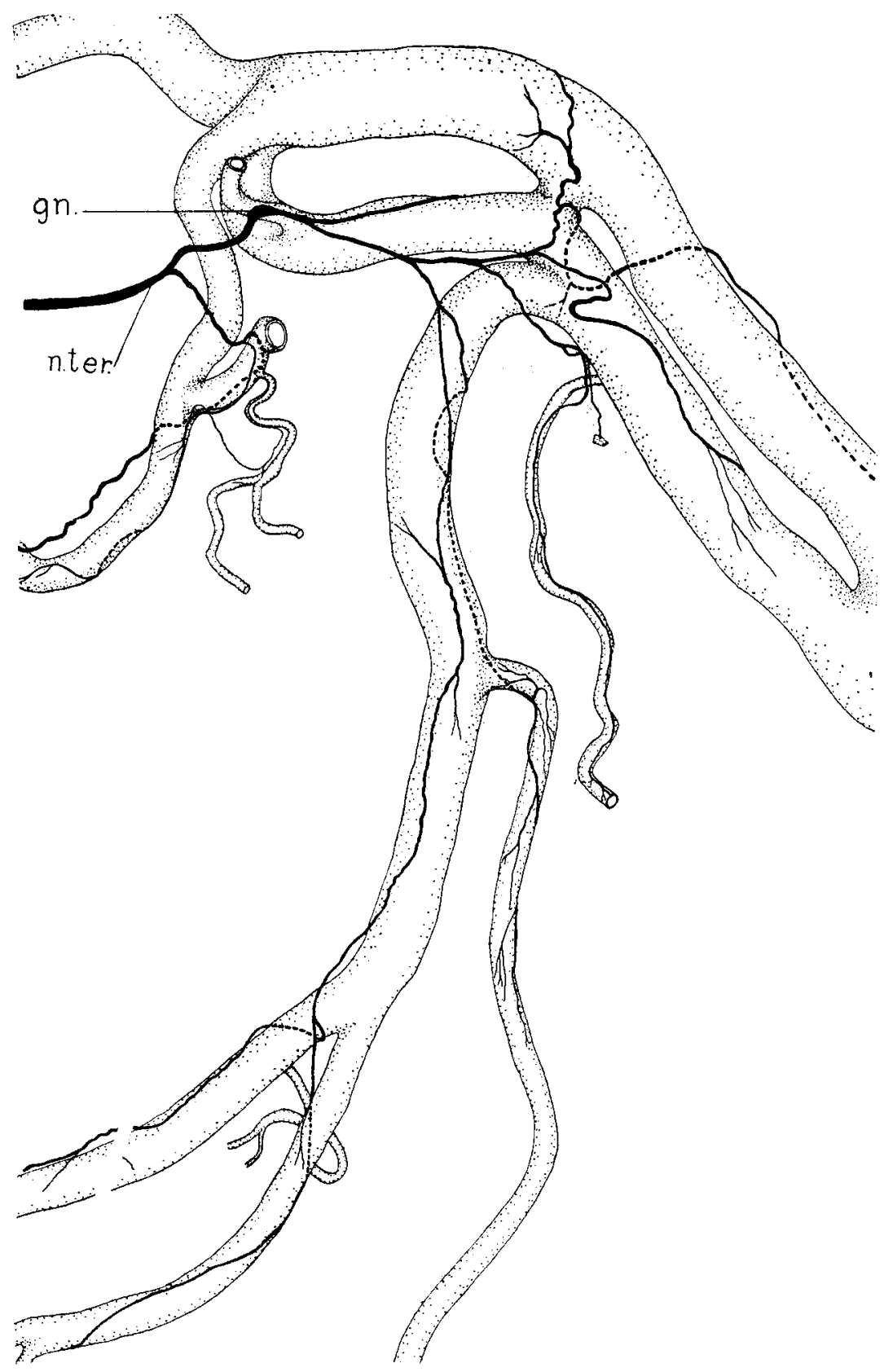

Fig. 33 Portion of left nervus terminalis and related vessels shown in figure 32 , enlarged to show the distribution of strands to the walls of the blood-vessels. 
brain, both on the ventral surface and in the sagittal fissure. In all cases in which their connection could be determined, when followed toward the ventral surface of the brain such strands led to the principal branches of the anterior cerebral artery, and connected with the main nerve bundle of the terminalis. When the overlying connective tissues were successfully removed the white nerve strands stood out clearly against the reddish brown of the blood-vessels. The larger bundles were followed with comparative ease even with the unaided eye, and were not easily torn. It is unlikely that all of the finer bundles were left intact. The relatively long stretches on some of the arteries shown in figure 33 where no twigs are represented probably indicate areas where they were inadvertently torn in dissection. Those shown in other parts of the vessels could be raised upon the point of a needle and stretched in such a manner as to clearly show that the finer twigs into which they ramify enter the walls of the blood-vessels.

Caudally, the principal roots which by their union form the nerve trunk, follow along the larger vessels as far as the latter could be traced without cutting into the brain. In most of the specimens examined the internal carotid artery had been severed so close to the brain in removing the organ that it was not possible to determine with certainty that any of it was present. There seems little doubt, however, that the continuation of strands from the main trunk of the terminalis unites with the plexus surrounding the internal carotid.

A.branch from the main bundle was also followed along the posterior ramus of the anterior cerebral artery as far as the genu of the corpus callosum, and similarly on other rami of this vessel nerve strands were observed.

Evidence of direct connection with the brain was difficult to obtain. Delicate branches from the nerve strands on the arteries were found occasionally to enter openings in the anterior perforated space. These branches were extremely difficult to disentangle from the mass of small blood-vessels, connective tissue, and elastic fibers among which they were found. Many appeared to be related to the larger vessels which enter the brain 
substance in this region. In the material examined, only one relatively large strand (fig. 32, c) was seen to enter the brain. This compared in size with the strands which enter the mule's brain (figs. 40, 41, 42).

Although the peripheral relations in the beef could not be determined in the available adult material, dissection of a number of ox fetuses of $110 \mathrm{~mm}$. to $140 \mathrm{~mm}$. greatest length brought

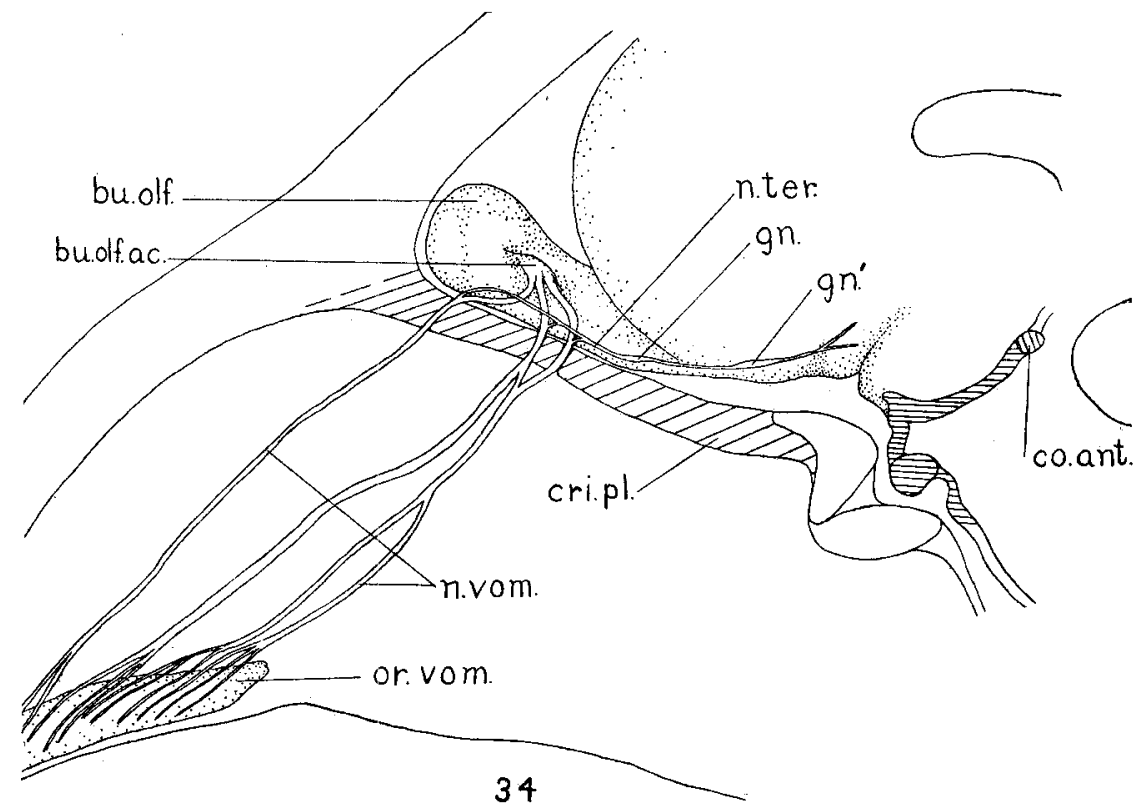

Fig. 34 Part of the nasal septum and the cerebral hemisphere of fetal ox of $121 \mathrm{~mm}$. greatest length, showing the nervus terminalis, the vomeronasal nerves, and a portion of the vomeronasal organ. This drawing was combined from several dissections and is to that extent diagrammatic. $\times 4$.

out the fact that in the beef, as in the other mammals studied, the terminalis passes through the cribriform plate in company with the vomeronasal nerve, and doubtless spreads out on the septum in the characteristic plexiform manner observed in other mammals.

As shown in figure 34 , which represents the relations in a fetus of $121 \mathrm{~mm}$. greatest length, the main nerve bundle divides 
on approaching the cribriform plate into three strands, each of which unites with one of the bundles of the vomeronasal nerve. No differentiation between the terminalis and the vomeronasal nerve could be seen after the two had joined. Since they are separate in the cat, rabbit, horse, and human, there can be little doubt that differential staining methods would show the two as distinct in the septal region of the beef also. Attention may be directed at this point to the two ganglia which are visible on the

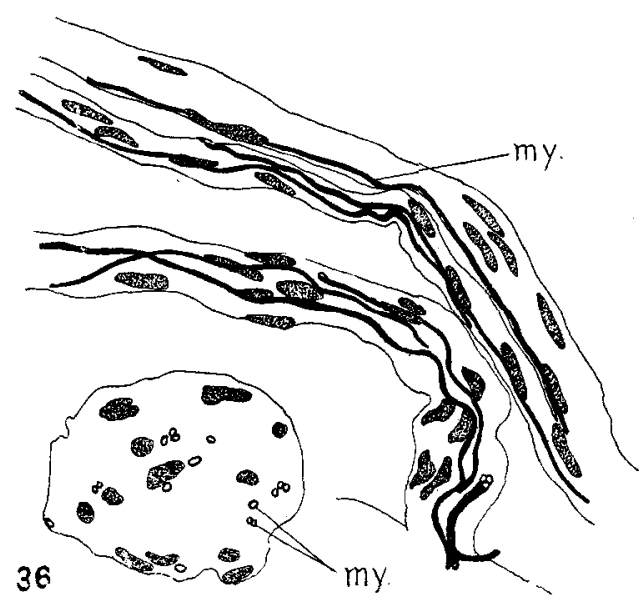

Fig. 35 Longitudinal section of two nerve strands accompanying anterior cerebral artery of the beef, showing myelinated fibers. Formalin fixation, ironhematoxylin stain. Sections $10 \mu . \times 450$.

Fig. 36 Transverse section of relatively large nerve strand parallel to anterior cerebral artery of beef, showing myelinated fibers. Formalin fixation, iron-haematoxylin stain. Sections $10 \mu . \times 450$.

main central bundle of the nerve in the fetus and to the two roots at its central end. These roots appeared to enter the brain substance near the fissura prima.

Histological. The composition of the main nerve bundle in the adult, and of the principal strands which run parallel with the several branches of the anterior cerebral artery, was determined by the study of sections. As shown in figure 36, which represents a cross-section of one of the larger strands on the internal frontal branch of the anterior artery cerebral, sixteen 
very delicate myelin sheaths are present, as brought out by iron-haematoxylin staining. More slender nerve strands in the same preparation showed a smaller number of myelinated fibers. In longitudinal sections (fig. 35) the myelin sheaths are shown to continue without interruption for considerable stretches. They measure from $1.5 \mu$ to $2 \mu$ in diameter.

Sections of the main trunk peripheral to the ganglionic masses revealed a much larger number of myelin sheaths. In the section illustrated (fig. 37) which was stained by the Weigert method, sixty-four delicate sheaths are visible. Attention may also be called in this connection to the many fasciculi, fifteeen in number, which enter into the formation of the larger bundle.

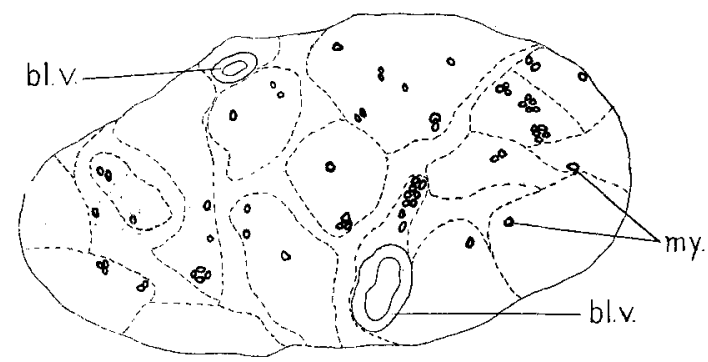

Fig. 37 Transverse section of main trunk of nervus terminalis of beef, showing distribution of myelinated fibers. Formalin fixation, Weigert stain. $\times 360$.

Great care was exercised to prevent decolorizing any of the sheaths during the process of differentiation, when those methods were employed which required caution. In view of the partial degeneration which had taken place in some of the sheaths, it is possible that this process had reached a stage in some fibers at which the staining methods employed were no longer effective in differentiating the myelin. It is believed, however, that the majority of myelinated fibers were stained. The remaining portion of the nerve strand was assumed to be made up of unmyelinated fibers. These observations were subsequently confirmed in material which was fixed in osmic acid shortly after the animal was slaughtered. 
An attempt was made to analyze those roots which penetrate into the brain, using the osmic-acid material. The few roots which were successfully isolated were of small size. They were removed and mounted whole in glycerin. One or two myelin sheaths were observed in each case, the remainder of the root being evidently composed of unmyelinated fibers. They thus resemble, except in size, the strands on the arterial walls.

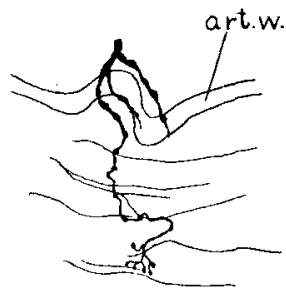

$38 \mathrm{~B}$

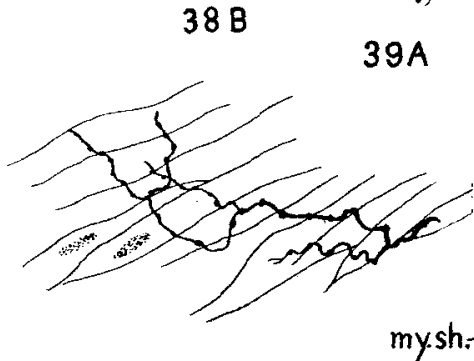

$38 \mathrm{~A}$

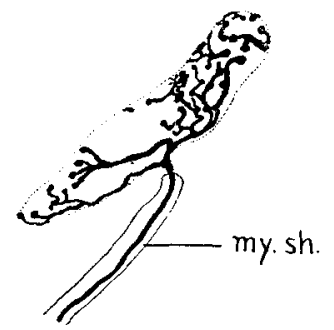

$39 A$

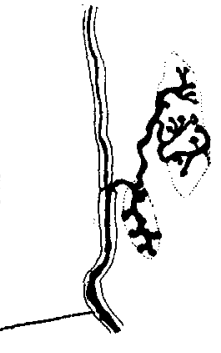

$39 B$

Fig. $38^{\circ} \mathrm{A}$ and $\mathrm{B}$ Motor terminations in muscular layer of anterior cerebral artery of beef. A illustrates the typical appearance, B showed slight terminal knobs. Gold-chloride technique. $\times 733$.

Fig. $39 \mathrm{~A}$ and B Sensory nerve terminations in wall of anterior cerebral artery of beef, illustrating typical spindle-like outline and myelinated fibers. A represents a typical termination, B shows two smaller ones attached to a common branch. Gold-chloride technique. $\times 733$.

Nerve terminations. The frozen beef brains responded well to the gold-chloride treatment, and terminations of the twigs which enter the muscular walls of the blood-vessels were found. These nerve endings, as in the cat, are of two types. Type I (fig. 38, $A$ and $B$ ) consists of delicate varicosed fibers which ramify and run for varying distances among the unstriated muscle cells. 
These fibers are unmyelinated, and correspond in appearance with those previously described in the cerebral vessels of the cat. They are present at various levels of the muscular coat of the arterial wall, as shown in cross-sections. They send their twigs between the smooth muscle cells in the typical manner of motor terminations in this type of muscle. As previously stated, it seems probable that they should be regarded as motor endings.

The terminations which have been designated as Type II are, as in the cat, strikingly different in appearance (fig. 39, A and B) from those of Type I. The nerve fiber leading to these is myelinated, as indicated by a reddish cylinder surrounding the purplish-black of the central axis. The myelin sheath in most cases continues almost to the spindle-shaped termination. The axis, after emerging from the sheath, divides into two or three main rami which give off a varying number of short processes. These processes terminate invariably in rounded knobs. The portion of the spindle-shaped organ which was not occupied by these processes appeared nearly clear or had a slight bluish tint and was slightly granular. It stood out in strong contrast to the purplish red of the surrounding muscle cells.

The spindles in the beef showed considerable variation in size. Of those measured, the smallest were $4 \mu$ in diameter and $12 \mu$ in length. The largest were $6 \mu$ to $7 \mu$ in diameter and $35 \mu$ in length. The majority appeared to be about $5 \mu$ by $25 \mu$ to 30 $\mu$. Figure 39 illustrates one of the largest observed (A) and also an example of the smallest size (B) drawn to the same scale. It will be noted that the two end-organs represented in figure $39 \mathrm{~B}$ are the terminations of what appeared to be a branch of the larger fiber shown in the figure. A node is seen in the myelin sheath, through which the branch to these terminal organs passes. In a few instances it was possible to follow the myelinated fiber to the external surface of the artery and for a little way beyond.

\section{The nervus terminalis of the mule and the horse}

The mule. As represented in figure 40, the nervus terminalis of the mule runs parallel to the olfactory tracts, between them and the sagittal fissure of the brain. The nerve in both the mule 
and the horse, as in the beef, may be easily seen with the unaided eye. As shown in the figure, the left nerve had two compact ganglia. The right nerve had a single ganglionic mass of larger size. The larger of the two ganglia of the left nerve, which was the one more rostrally situated (figs. 40 and 43), was about 2 $\mathrm{mm}$. long and $\frac{1}{2} \mathrm{~mm}$. in diameter. The smaller ganglion was of about one-half the volume of the other.

The peripheral ends of both nerves were frayed and had the appearance of having been broken, doubtless where they subdivided into strands similar to those observed in the cat and in the horse. The anterior ends of the olfactory bulbs had been torn off in removing the brain from the cranial cavity, so it was not possible to study the relation of the terminalis to the vomeronasal nerves in this specimen. The main bundles of the nerve lay outside the pia mater as far caudally as several millimeters rostrad to the ganglia. Here they pierced the pia and in their further course centrally lay between this and the brain surface.

Immediately caudal to the posterior ganglion of the left nerve, and slightly more caudad to the single ganglion of the right nerve, the main bundle divides into a number of strands or rootlets. For convenience, the description will be confined to the left nerve, but in all essential respects, unless indicated to the contrary, the same statements apply to the right nerve also.

As shown in figures 40 and 43 the main trunk of the nerve is formed by the union of three strands. Two of these, the mesial one and the lateral (figs. 40 and 41), follow a course closely parallel to two of the branches of the anterior cerebral artery, and give off delicate rami to them. These twigs enter the walls of the vessels in the same manner as has already been described in the ox.

The relation of the medial of the three roots to another branch of the anterior cerebral artery is shown in figures 40 and 41 at $a$. Figure 40 represents the left hemisphere of the brain as viewed from the medial side. In figure 41 a portion of the same surface is represented on a larger scale, as seen through the binocular microscope. It will be noted that strand $a$ turns so as to run nearly at right angles to the main nerve bundle and follows the 
course of the artery. The nerve strand soon divides into two smaller strands, one of which had been inadvertently cut in separating the hemispheres. The severed portion may be seen on the stump of the artery, which it was ascertained belongs to the right hemisphere of the brain.

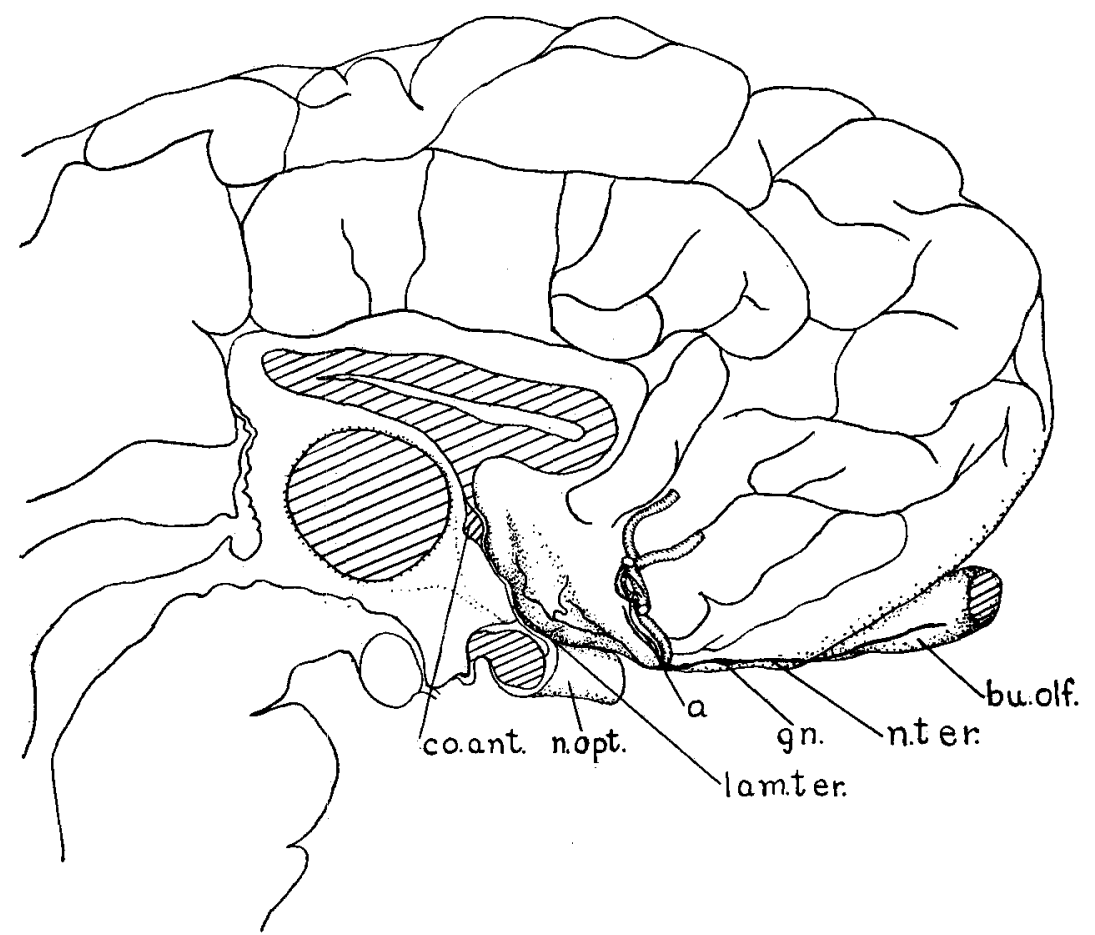

Fig. 40 Mesial view of left hemisphere of full-term mule fetus, showing the nervus terminalis. Slightly enlarged.

The middle root of the left nerve, as also shown in figures 40 and 41, runs toward the perforated area in front of the lamina terminalis. At first it is roughly parallel with the anterior cerebral artery, then turning upwards, it gives off a small ramus which enters the brain through a perforation in the furrow of the small sulcus (posterior parolfactory) shown in the figure. Another ramus of slightly larger size is given off a little further caudad. This, and the caudally continuing main strand, also enter the 

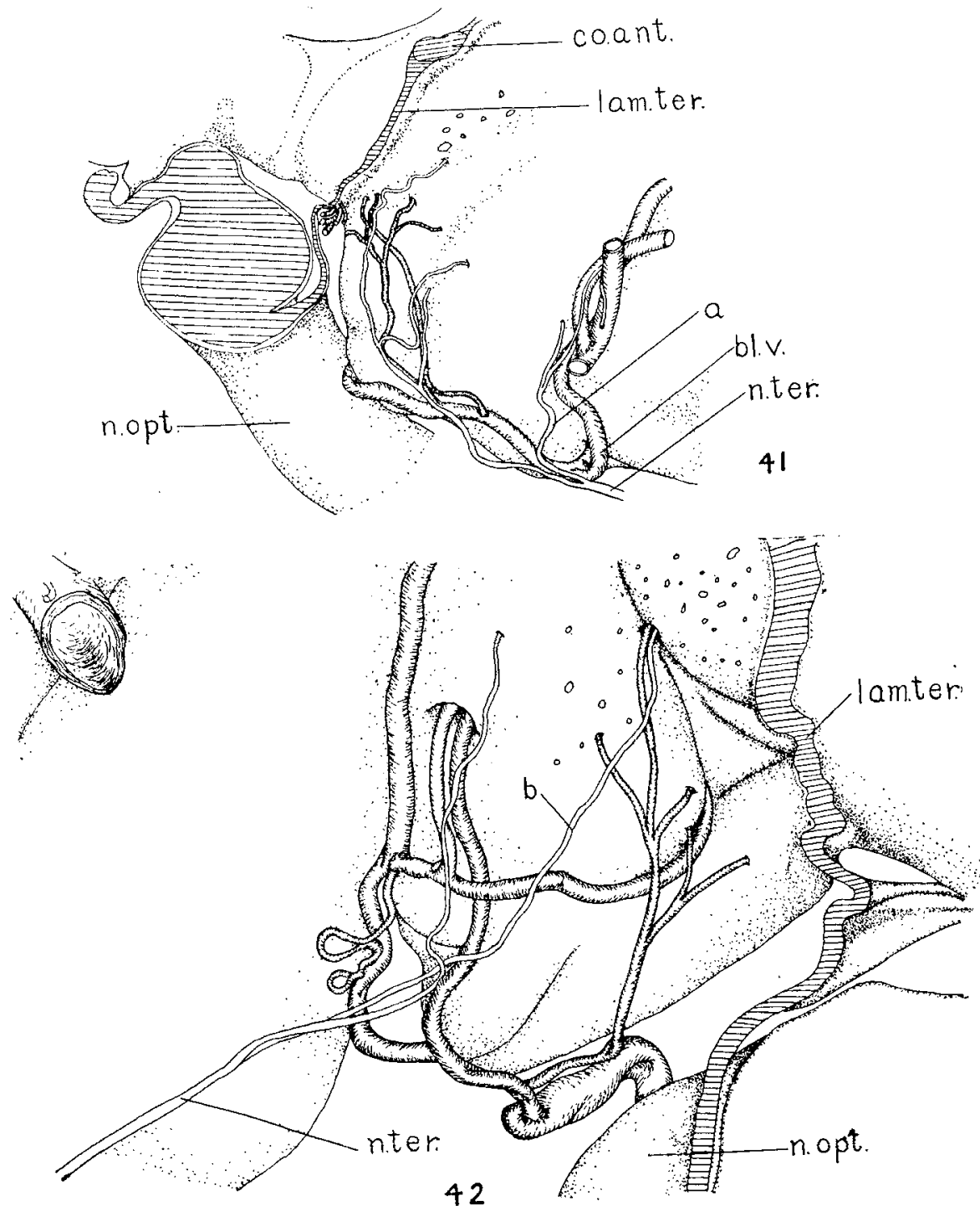

Fig. 41 Central connections of the left nervus terminalis of full-term mule fetus, illustrating relations to neighboring blood-vessels and points of entrance into brain substance. $\times$ ea. 5 .

Fig. 42 Central relations of right nervus terminalis of mule fetus. $\times$ ea. 9 . 
brain substance, the one slightly rostrad to the sulcus previously mentioned, the other at a point about $2 \mathrm{~mm}$. anterior to the lamina terminalis, and somewhat more than midway between the anterior commissure and the ventral border of the brain.

As already stated, essentially the same conditions are found on the right side of the same specimen (fig. 42). Here, however, only two roots were found which enter the brain substance. The larger one $(b)$ enters through the same opening as does one of the blood-vessels of medium size. This was the only case observed in the mule where a nerve strand of the terminalis and a bloodvessel enter the brain together. Other rootlets enter very near the openings through which other blood-vessels pass. The main nerve trunks on both sides are very clearly formed by the union of the roots described, with the possible addition of other smaller ones which may have been torn and lost during the dissection.

The left nerve was removed from its attachments to make possible a closer study of its structure. As represented in figure 43 , the three principal roots merge into the smaller ganglion. Rostrally from this ganglion the nerve is compactly enclosed in a sheath of connective tissue. A few millimeters rostrad from the small ganglion is the larger one previously noted. Continuing forward from this point, the nerve remains as a compact bundle as far as the place where it had been broken in removing the brain from the cranial cavity.

A very slender blood-vessel (fig. 43, bl.v.) winds around the nerve for the greater part of its course. At intervals this vessel gives off branches which penetrate into the nerve bundle.

Histological. Sections of the ganglia stained with thisnin reveal a considerable variety in the form of the ganglion cells. The sections were cut $18 \mu$ and $20 \mu$ thick, so that the processes could be followed in many instances for some distance. As illustrated in figures 44 to 47 , all variations of type from simple bipolar, to cells having at least five processes occur. Numerous binucleated cells (fig. 47) were observed. Of the 292 ganglion cells which were found in the single ganglion of the right nerve, twenty-seven were binucleated, or 9.25 per cent. Sections cut at $10 \mu$ and stained with haematoxylin showed the same types of cells in the two ganglia of the left nerve. 


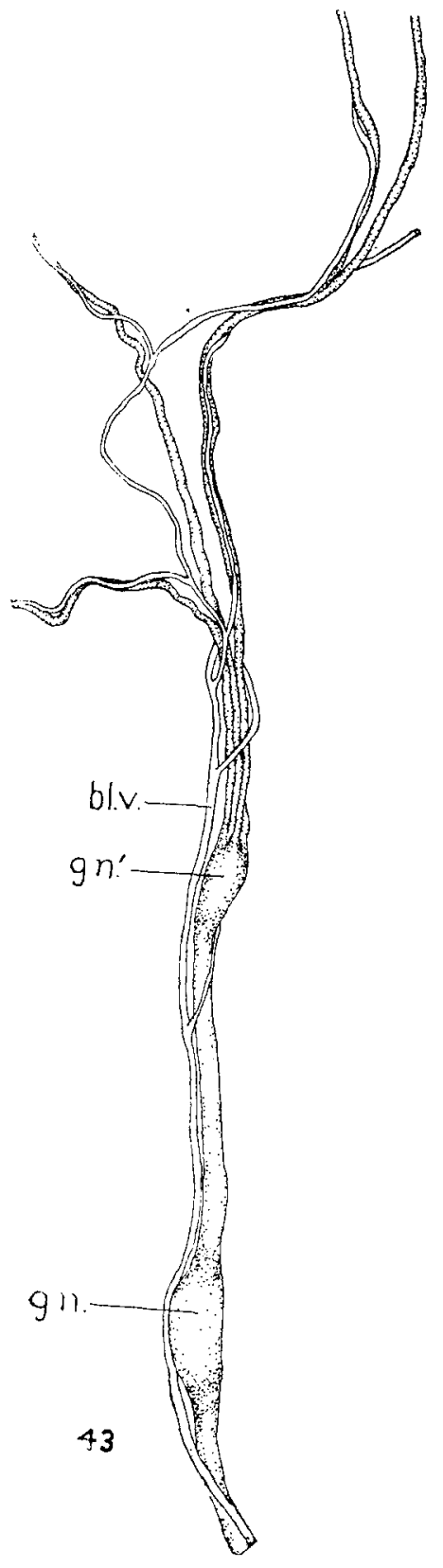

Fig. 43 Left nervus terminalis of mule fetus at full term, removed from its connections. Only the ganglia, with portions of the main trunk and of the central roots are represented. 
Some attention was given to the arrangement of the chromatophile granules in the cells. Carpenter and Conel ('14) have pointed out the characteristic peripheral arrangement of this substance in ganglion cells of the sympathetic system, and hold this to be a distinguishing mark which differentiates them from cells of the cerebrospinal system. The granules are said to be scattered throughout the body of the perikaryon in ganglion cells of the central system. No very satisfactory results were obtained with the material available. Many of the cells (figs. 44 and 45) are seen to have a somewhat peripheral arrangement of the granules, while the other cells figured do not give suffcient indication of such distribution of granules to be noticeable. It should be stated, however, that the sections stained with thionin, which would affect the Nissl bodies, were too thick to be favorable for such a study.

An effort was made to demonstrate myelinated fibers, if present, and to learn, if possible in the large central roots of the terminalis of the mule, the relative number of such fibers to the number in the main peripheral trunk. The osmic acid, ironhaematoxylin, Weigert, and Stroebe methods were each tried, with variations, a number of times. No success was had in demonstrating myelin sheaths. In some of the preparations delicate fibers of small diameter were visible, but it was not possible to trace them continuously through more than three or four sections of a series. In the central roots from two to four such sheath-like structures were present in some of the sections. In others none could be seen. The peripheral bundle showed as many as sixteen in certain sections. The results of this part of the study were on the whole negative. Either the myelin sheaths are not well developed in the nervus terminalis at this stage of fetal life of the mule or the formalin preserved material did not respond to the methods employed for their demonstration.

The Horse. The nervus terminalis of the horse brain examined (fig. 48) consists centrally of four principal strands which unite near the base of the olfactory stalk to form a broad, flattened nerve trunk. This trunk continues rostrally as a compact bundle as far as the posterior part of the bulbus olfactorius, receiving 
a number of delicate strands in this part of its course. Many of these strands were traced caudally to neighboring blood-vessels. The shrunken condition in which these vessels were found, however, did not favor an attempt to find twigs, such as were observed in the beef, which pass into their muscular walls. At the region where the olfactory stalk swells to form the bulbus olfactorius, the main trunk of the terminalis divides into five relatively large strands and a number of smaller ones. A few millimeters caudally of this point a single strand is given off, which appears to pass laterally and beneath the olfactory stalk. The five larger strands continue rostrally, anastomosing with the finer strands and with one another, and thus form a plexus very similar

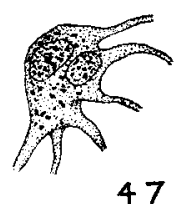

47

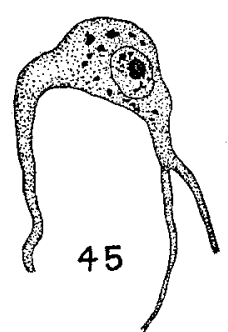

Figs. 44-47 Ganglion cells from ganglion terminale of full-term mule fetus. Formalin fixation, thionin stain. $\times 550$.

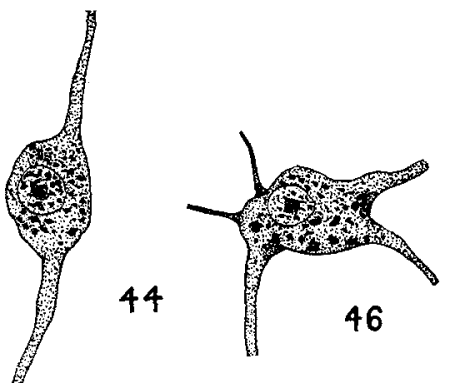

to that observed in the eat (figs. 1 and 3) and in the dog (fig. $49)$.

About $3 \mathrm{~mm}$. rostrad to the point where these strands assume a separate course, and lying in the path of the largest of the five, is a large flattened ganglion (fig. 48. gn.) of irregular outline. This ganglion receives fibers also from other strands of the plexus than the one in whose apparent course it is placed, so that it lies in the midst of the plexus.

A much smaller ganglion $\left(g n^{\prime},\right)$ is present caudally, on the main trunk midway between the larger ganglion and the point of union of the central roots.

Rostrally of the main ganglion, two of the larger strands enter the sheath of connective tissue which encloses the vomeronasal 
nerve in its passage through the cribriform plate. One enters dorsally of the latter nerve trunk and the other on its ventral side. The vomeronasal nerve differs in the horse examined from the condition found in the other mammals studied in that it

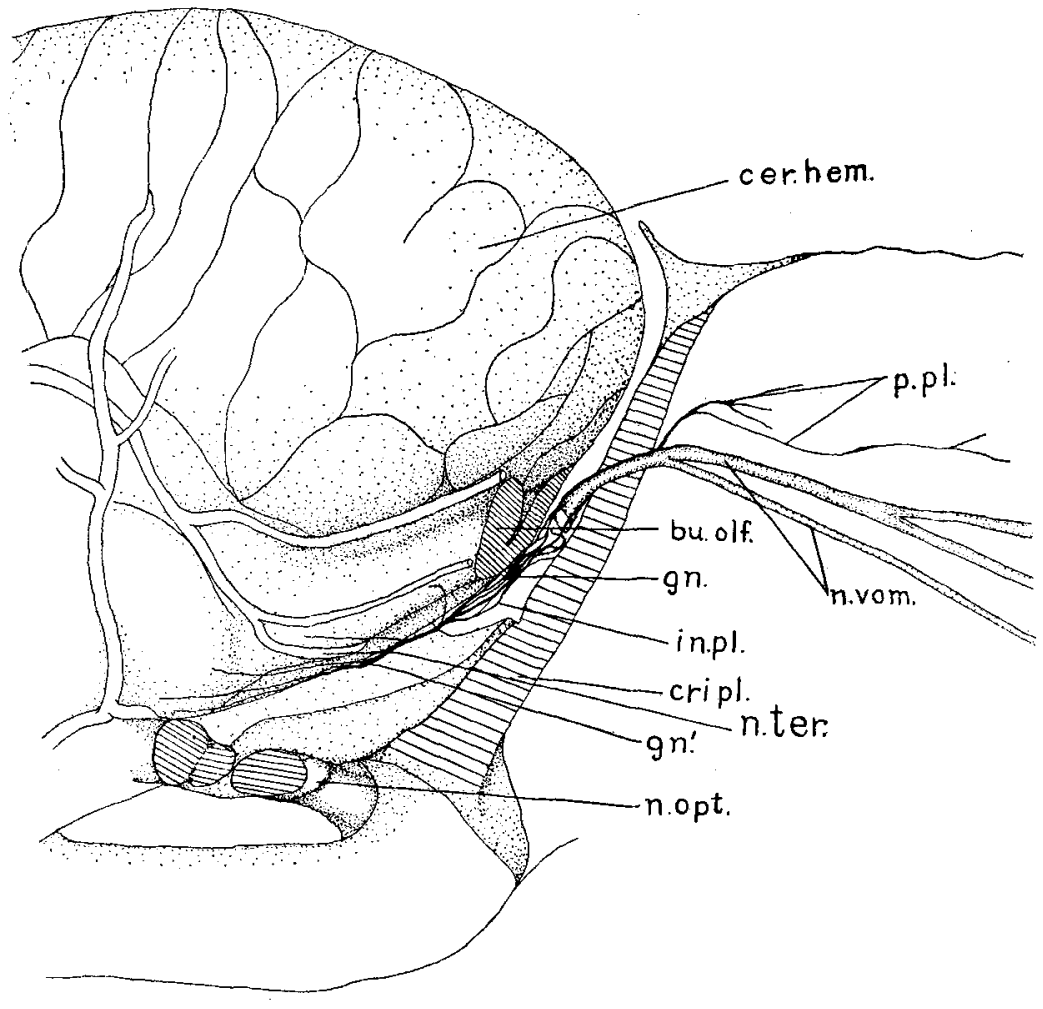

Fig. 48. Ventrolateral view of forward portion of the brain and of part of the nasal septum of the horse, showing the relations of the nervus terminalis: The olfactory bulb was removed to bring into view the ganglion terminale and the intracranial plexus, from the angle at which the dissection was made.

does not divide into the eharacteristic number of bundles until it has passed through the bony plate as a single compact trunk, surrounded by a heavy sheath. A relatively large strand of the terminalis penetrates this sheath immediately distal to the point 
of emergence of the vomeronasal bundle from its foramen. This strand assumes an independent course, running dorsally a little way, then divides into a number of smaller strands whose general course is rostrally. These become so attenuated by repeated division that it was not possible to follow their finer ramifications by dissection. Apparently they form a portion of a plexus similar to that found in the cat and in other mammals.

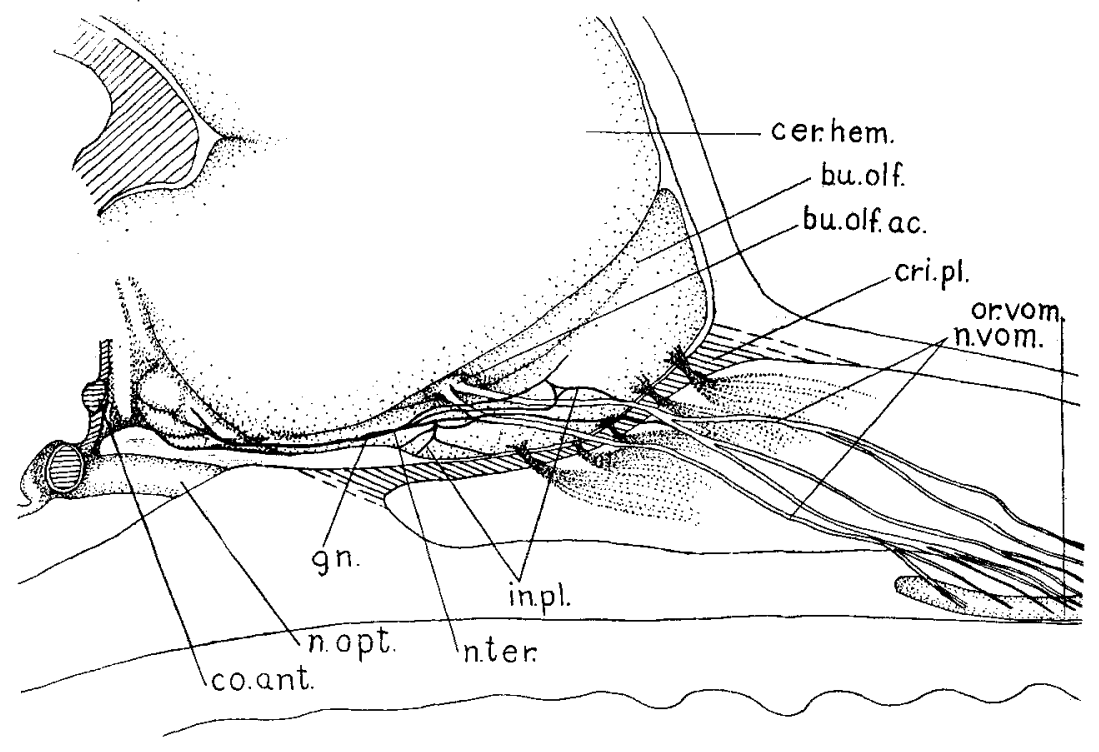

Fig. 49 Anterior portion of cerebral hemisphere and a portion of nasal septum of a puppy two weeks old (estimated) showing nervus terminalis.

The course of the nerve strands in the septum was followed to some extent by the expedient of stripping off the thick mucosa from the bony septum and examining its deeper surface. This required a minimum of dissection, as the nerve strands lay for the most part in the deeper portion of the mucosa. The proximal portions of the first two divisions of the vomeronasal nerve lay in rather deep furrows in the bony septum, and the strands of the terminalis which accompany the larger nerve through the cribriform plate, accordingly, emerge from the sheath very close to the periosteum of the bony septum. In addition to the rami 
of the bundle just noted, other strands were observed in the septum which also appeared to form a part of the terminalis plexus.

Returning to the other intracranial strands which were noted distally of the ganglion terminale, the most dorsal one was somewhat torn in dissection, but appeared to have passed between the olfactory bulb and the cerebral hemisphere. The remaining fibers appear to pass through the cribriform plate in company with bundles of olfactory fibres, ventral to the vomeronasal foramen. Such fibers could not be found distally of the plate. Possibly the strands in the septum which were noted in connection with those which emerge in company with the" nervus vomeronasalis are distal continuations of the strands now under discussion. The connections in the bony plate might easily have been inadvertently injured to such an extent that the strands immediately distal to the plate were completely destroyed.

\section{The nervus terminalis in other mammals}

The observations of the nervus terminalis of the dog, squirrel, and human, and in embryos of the pig, sheep, and rabbit, were less extended than those described in the preceding pages. So far as they were carried, they agreed with the findings in the other animals studied. The nerve was found in the typical relation to the vomeronasal bundles, and passes through the cribriform plate in company with these.

Only one ganglion was found in the dog. This is situated near the vomeronasal nerve, and is long and fusiform (fig. 49). In the squirrel also (not figured) one large ganglion was present at the point where the main trunk of the terminalis splits into strands similar to those found in the cat and the horse, which accompany the larger bundles of the vomeronasal nerve through the bony plate. A number of smaller strands, which appeared to correspond with the intracranial plexus found in the other animals, were observed. It may be noted that in the squirrel the accessory olfactory bulb lies on the dorsolateral side of the bulbus olfactorius so as to be invisible when the brain is viewed from the medial side. 
As already stated, the attempt to find strands from the terminalis to the blood-vessels of the human brains was not successful. Nerve strands similar to those present on the anterior cerebral artery of the beef and the mule were found and small twigs were observed to enter the walls of the corresponding vessels of the human material. Efforts by the gold-chloride and Bielschowsky methods to demonstrate nerve terminations in these vessels were not satisfactory with the material available.

The studies on the embryonic material did not serve to reveal any features not already known.

\section{SUMMARY AND COMMENTS}

1. The nervus terminalis of mammals is made up in part, at least, of sympathetic fibers, and its ganglionic clusters contain sympathetic cells. The wide distribution and large number of fibers of the peripheral plexus (as noted by Brookover), in comparison with the small size of the central connections, resemble the relation of preganglionic fibers to the postganglionic fibers of the sympathetic system. This resemblance is strengthened by the occurrence of pericellular baskets on many of the ganglion cells of the intracranial clusters.

2. Two types of neurones are present in the terminalis, namely, 1) sensory and 2) motor.

3. Some of the sensory fibers end in the muscular walls of the anterior cerebral artery and its branches by a type of nerve termination hitherto undescribed in cerebral blood-vessels.

4. There is some evidence that free nerve terminations in the epithelium of the septal mucosa and of Jacobson's organ are also connected with afferent neurones of the nervus terminalis. For the present it is assumed that these free sensory terminations belong to a sensory component of the nervus terminalis which is distinct from sympathetic afferent fibers which have terminations in the walls of the blood-vessels.

The type of nerve endings and their position in the mucosa would seem to indicate that this component is part of the general visceral afferent system. The early embryonic history of the nerve in ganoids and selachians might, however, point to a rela- 
tionship with the special visceral afferent group. As previously noted, Brookover states that the origin of the nervus terminalis in the ganoid fishes studied by him is from a portion of the olfactory placode. Locy, in describing its early development in Squalus, attributes its origin to the neural crest, but states also that "The new nerve has at first a fusion (placode) with the thickened surface epithelium, located just above the shallow depression that marks the beginning of the olfactory pit. This connection between the surface epithelium and brain-wall, consists of a group of closely packed cells in which I have failed at this early stage [6 to $8 \mathrm{~mm}$.] to recognize fibers." If this placode described by Locy be homologous with that found by Brookover, the embryonic evidence in the two groups on which these writers worked points to an origin which in part at least corresponds to that of other special sensory ganglia in the head region.

In connection with the free nerve terminations described, this embryonic origin of the nerve from a placode suggests the conclusion that there is a sensory component of the terminalis which is distinct from the sensory fibers which terminate in the walls of the blood-vessels. The neuroblasts which have their origin in the neural crest might well give rise to the sympathetic cells described and figured in the present article, and which have been described in other groups of vertebrates than the mammals in the nerve under consideration. The free nerve terminations in the mucosa do not, however, seem to fit in with the view that this sensory component belongs to the special visceral system.

5. Many physiologists find insufficient evidence of vasomotor control of the cerebral blood-vessels. Wiggers ('05, '08) and Weber ('08) have presented experimental support of the histological evidence. Both conclude that there is direct physiological proof of nerve control over the cerebral vessels. Weber, moreover, finds indications that there is an accessory vasomotor center further rostrad in the brain than that situated in the bulb.

This observation is suggestive, in connection with McKibben's findings in urodeles, of terminalis tracts extending to the interpeduncular region, with a probable center in the neighborhood of the preoptic nucleus. 
6. If connection of the nervus terminalis with such a center in the forward part of the brain should be demonstrated, the forebrain should be included in the list of those divisions of the central nervous system which are directly related to the sympathetic system.

7. The evidence now at hand points to the conclusion that the nervus terminalis of mammals is functional. Its relatively small size in this group as compared with its development in selachians, may indicate that its functional importance is reduced.

8. Innervation by the nervus terminalis of the vomeronasal organ, which appears to occur to some extent, is merely incidental.

\section{BIBLIOGRAPHY}

Alexander, W.T. 1875 Bemerkungen über die Nerven der Dura Mater. Archiv für Mikros. Anat., Bd. 11, S. 231.

Allis, E. P. 1897 The cranial muscles and the cranial and first spinal nerves in Amia calva. Jour. Morph., vol. 12, no. 3.

Barogh, C. 1860 Das Jacobson'sche Organ des Schafes. Sitzungsb. d. Kais. Akad. d. Wissenschaften in Wien, Bd. 42, S. 449.

BARDEEN, C. R. 1903 The growth and histogenesis of the eerebrospinal nerves in mammals. Am. Jour. Anat, vol. 2, pp. 231-257.

BAwdis, H. H. 1894 The nose and Jacobson's organ with especial reference to Amphibia. Jour. Comp. Neur., vol. 4, pp. 117-152.

BEDFond, E. A. 1904 The early history of the olfactory nerve in swine. Jour. Comp. Neur., vol, 14, pp. 390-410.

Belogolowy, G. 1912 Studien zur Morphologie des Nervensystems der Wirbelthiere. I. Die Entwickelung des Nervus terminalis bei Selachiern. Bull. Soe. Nat. Moscou, vol. 25.

Bing, R., ANd Burckhardt, R. 1904 Das Centralnervensystem von Ceratodus forsteri. Anat. Anz., Bd. 25, S. 588-599.

1905 Das Centralnervensystem von Ceratodus forsteri. Semon Zoöl. Forsch., in Jenaische Denkschr., Bd. 4.

Brookover, Chas. 1908 Pinkus's nerve in Amia and Lepidosteus. Science, N. S., vol. 27, p. 913.

1910 The olfactory nerve, nervus terminalis and preoptic sympathetic system in Amia calva, L. Jour. Comp. Neur., vol. 20, pp. 49-118.

1914 a The development of the olfactory nerve and its associated ganglion in Lepidosteus. Jour. Comp. Neur., vol. 24, pp. 113-130.

$1914 \mathrm{~b}$ The nervus terminalis in adult man. Jour. Comp. Neur., vol. 24, pp. 131-135.

1917 The peripheral distribution of the nervus terminalis in an infant. Jour. Comp. Neur., vol. 28, pp. 349-360.

Brookover, Chas., and JACKson, T. S. 1911 The olfactory nerve and the nervus terminalis of Ameiurus. Jour. Comp. Neur., vol. 21, p. 237. 
C.AJAL, S. R. 1893 Neue Darstellung vom histologischen Bau des Centralnervensystems. Arch. für Anat. u. Phys., Ant, Abtheil., p. 393.

1905 a Tipos celulares de los ganglios sensitivos del hombre y mamiferos. Trab. del Lab. de Inves. Biol. de la Univ. de Madrid, T. 4, p. 1. $1905 \mathrm{~b}$ Las celulas del gran simpatico del hombre adulto. Trab. del Lab. de Inves. Biol. de la Univ. de Madrid, T. 4, p. 79.

1911 Histologie du Système Nerveux de L'Homme, T. 2, p. 670.

Carpenter, F. W. 1911 The ciliary ganglion of birds. Folia Neurobiologica, Bd. 5, S. $738-754$.

1912 On the histology of the cranial autonomic ganglia of the sheep. Jour. Comp. Neur., vol. 22, p. 447.

Carpenter, F. W., AND Conel, J, L. 1914 A study of ganglion cells in the sympathetic system, with special reference to intrinsic sensory neurones. Jour. Comp. Neur., vol. 24, p. 269.

Carpenter, F. W., and Main, R. C. 1907 The migration of medullary cells into the ventral nerve-roots of pig embryos. Anat. Anz., Bd. 31, S. $303-306$.

Cole, Frank J. 1896 The cranial nerves of Chimaera monstrosa. Proc. Roy. Soc. Edinburgh, vol. 21, pp. 49-56.

Devries, E. 1905 Note on the ganglion vomeronasale. K. Akad. van Wetenschappen te Amsterdam, vol. 7, p. 704.

Dogies, A. S. 1895 Zur Frage über den feineren Bau des sympathischen Nervensystems bei den Säugethieren. Arch. für Mikros. Anat. und Entwick., Bd. 46, S. 305-344.

$1896 Z_{\text {wei }}$ Arten sympathischer Nervenzellen. Anat. Anz., Bd. 11, S. $679-687$.

1898 Die sensiblen Nervenendigungen im Herzen und in den Blutgefässen der Säugethiere. Arch. für Mikros. Anat. und Entwick,,. Bd. 52 , S. 44-70.

1908 Der Bau der Spinalganglien des Menschen und der Säugethiere. Jena.

Döltken, A. 1909 Ursprung und Zentren des Nervus terminalis. Monatsschr. f. Psych. u. Neur., Erg. Heft, Bd. 26, S. 10.

Fritsch, G. 1878 Untersuchungen über den feineren Bau des Fischgehirns. Berlin.

FÜrbringer, K. 1904 Notiz über einige Beobachtungen am Dipnoerkopf. Anat. Anz., Bd. 24, S. 405-408.

HERRICK, C. JUDSON 1903 On the morphological and physiological classification of the cutaneous sense organs of fishes. Amer. Nat., vol. 37, pp. 313318.

1909 The nervus terminalis (nerve of Pinkus) in the frog. Jour. Comp. Neur., vol. 19, p. 175.

1916 Introduction to neurology. Philadelphia.

1917 The internal structure of the midbrain and thalamus of Necturus. Jour. Comp. Neur., vol. 28, p. 236.

HERRICK, C. L. 1893 Topography and histology of the brain of certain reptiles. Jour. Comp. Neur., vol. 3, p. 124.

Howeld, W. H. 1915 Text-book of physiology, 6th ed., p. 632. Philadelphia. 
Huber, G. Carl 1897 Lectures on the sympathetic nervous system. Jour. Comp. Neur., vol. 7, pp. 73-145.

1899 a Observations on the innervation of the intracranial vessels. Jour. Comp. Neur., vol. 9, pp. 1-25.

$1899 \mathrm{~b}$ A contribution on the minute anatomy of the sympathetic ganglia of the different classes of vertebrates. Jour. Morph., vol. 16, pp. $27-90$.

1913 The morphology of the sympathetic nervous system. XVII International Congress of Medicine, London.

Huber, G. C., and Dewitt, Lydia 1898 A contribution on the motor nerveendings and on the nerve-endings in the muscle spindles. Jour. Comp. Neur., vol. 7, pp. 169-230.

Huber, G. C., and Guild, Stacy R. 1913 Observations on the peripheral distribution of the nervus terminalis in Mammalia. Anat. Rec., vol. 7, pp. 253-272.

JoNes, W. C. 1905 Notes on the development of the sympathetic nervous system in the common toad. Jour. Comp. Neur., vol. 15, p. 113.

Johnston, J. B. 1906 The nervous system of vertebrates. Philadelphia. 1909 The morphology of the forebrain vesicle in vertebrates. Jour. Comp. Neur., vol. 19, pp. 457-539.

1911 The telencephalon of selachians. Jour. Comp. Neur., vol. 21, pp. 1-113.

1913 Nervus tcrminalis in reptiles and mammals. Jour. Comp. Neur., vol. 23, pp. 97-120.

1914 The nervus terminalis in man and mammals. Anat. Rec., vol.8.

Keibet and Mall 1912 Human embryology, vol. 2. Philadelphia.

KöLliker, A. 1896 Handbuch der Gewebelehre des Menschen, Bd. 2, S. 835.

Kuntz, Albert 1911 The evolution of the sympathetic nervous system in vertebrates. Jour. Comp. Neur., vol. 21, pp. 21 $\tilde{-}-236$.

1913 a The development of the cranial sympathetic ganglia in the pig. Jour. Comp. Neur., vol. 23, pp. 71-96.

$1913 \mathrm{~b}$ On the innervation of the digestive tube. Jour. Comp. Neur., vol. 23, pp. 173-192.

1914 Further studies on the development of the cranial sympathetic ganglia. Jour. Comp. Neur., vol. 24, p. 235.

LANDACRE, F. L. 1910 The origin of the sensory components of the cranial ganglia. Anat. Rec., vol. 4, pp. 71-79.

1916 The cerebral ganglia and early nerves of Squalus acanthias. Jour. Comp. Neur., vol. 27, p. 19.

Lanaley, J. N. 1900 The sympathetic and other related systems of nerves. Schäfer's Text-book of Physiology, vol. 2, pp. 616-696.

1903 The autonomic nervous system. Brain, vol, 26, pp. 1-26.

Locy, W. A. 1899 New facts regarding the development of the olfactory nerve. Anat. Anz., Bd. 16, S. 273-290.

1903 A new cranial nerve in selachians. Mark Anniv. Volume.

1905 a On a newly recognized nerve connected with the forebrain of selachians. Anat. Anz., Bd. 26, S. 33-63 and 111-123.

$1905 \mathrm{~b}$ A footnote to the ancestral history of the vertebrate brain. Science, N. S., vol. 27, pp. 180-183. 
Malone, E. T. 1913 Nucleus cardiacus nervi vagi and the three different types of nerve cells which innervate the three different types of muscle. Am. Jour. Anat., vol. 15, pp. 121-127.

MCCotter, R. E. 1912 The connection of the vomeronasal nerves with the accessory olfactory bulb in the opossum and other mammals. Anat. Rec., vol. 6, p. 299.

1913 The nervus terminalis in the adult dog and cat. Jour. Comp. Neur, vol. 23, p. 145.

1915 A note on the course and distribution of the nervus terminalis in man. Anat. Rec., vol. 9, p. 243.

1917 The vomeronasal apparatus in turtle and frog. Anat. Rec., vol. 12.

Mchibben, P. S. 1911 The nervus terminalis in urodele Amphibia. Jour. Comp. Neur., vol. 21, pp. 261-309.

1914 Ganglion cells of the nervus terminalis in the dogfish (Mustelus canis). Jour. Comp. Neur., vol. 24, pp. 437.

Michailow, S. 1908 Die Nerven des Endocardiums. Anat. Anz., Bd. 32. 1910 Uber die sensiblen Nervenendapparate der zentralen sympathischen Ganglien der Säugethiere. Jour. f. Psych. u. Neur., Bd. 16, S. 269 .

1911 Der Bau der zentralen sympathisehen Ganglien. Internat. Monatsschr. f. Anat. u. Phys., Bd. 28, S. 26.

MÜlleR, L. R., UND DAHL, W. 1910 Die Beteiligung des sympathischen Nervensystems an der Kopfinnervation. Deutsches Archiv f. klin. Med., Bd. 99, S. 48-107.

Norris, H. W. 1913 The cranial nerves of Siren lacertina. Jour. Morph., vol. 24, p. 254.

Pinkus, Felix 1895 Die Hirnnerven des Protopterus annectens. Morph. Arb. (G. Schwalbe), Bd. 4, S. 275.

1905 UUber den zwischen Olfactorius und Opticusursprung des Vorderhirn (Zwischenhirn) verlassenden Hirnnerven der Dipnoer und Selachier. Arch. Physiol. Jahrb., sup. Heft. 2, S. 447.

Prenriss, C. W. 1915 Text-book of embryology. Philadelphia.

Ranson, S. W. 1912 The structure of the spinal ganglia and of the spinal nerves. Jour. Comp. Neur., vol. 22, pp. 159-175.

1915 The vagus nerve of the snapping turtle (Chelydra serpentina). Jour. Comp. Neur., vol. 25, p. 301.

Ranson, S. W., and Billingsley, P. R. 1918 The superior cervical ganglion and the cervical portion of the sympathetic trunk. Jour. Comp. Neur., vol. 29 , no. 4.

READ, EFfie A. 1908 A contribution to the knowledge of the olfactory apparatus in the dog, cat and man. Am. Jour. Anat., vol. 7, pp. 17-47.

Rubaschin, W. 1903 t'ber die Beziehungen des Nervus trigeminus zur Riechschleimhaut. Anat. Anz., Bd. 22, S. 407.

Sheldon, R. E. 1908 The participation of medullated fibers in the innervation of the olfactory mucous membrane of fishes. Science, N. S., vol. 27, no. 702, p. 915 . 
Sheidon, R. E, 1909 The nervus terminalis in the carp. Jour. Comp. Neur. vol. 19 , p. 191.

1912 The olfactory tracts and centers in teleosts. Jour. Comp. Neur., vol. 22 , pp. 177-339.

Sheldon, R. E., and Brookover, Chas. 1909 The nervus terminalis in teleosts. Anat. Rec., vol. 3, p. 257.

Sherrington, C. S. 1911 The integrative action of the nervous system. New Haven.

Sewertzoff, A. N. 1902 Zur Entwickelungsgeschichte des Ceratodus forsteri. Anat. Anz., Bd. 21, p. 606.

Sminnow, A. 1895 Über die sensiblen Nervenendigungen im Herzen bei Amphibien und Säugethieren. Anat. Anz., Bd. 10, S. 737-749.

Smiti, G. Elliot 1895 Jacobson's organ and the olfactory bulb in Ornithorhynehus. Anat. Anz., Bd. 11, S. 161.

Streeter, G. L. 1912 The development of the nervous system. 4. The sympathetic nervous system. Human Embryology, Keibel and Mall, vol. 2, pp. 144-154.

von BrUnN, A. 1892 Die Endigung der Olfactoriusfasern in Jacobson'schen Organe des Schafes. Arch. f. Mikros. Anat. u. En丸wick., Bd. 39, S. 651.

von Lenhossé, M. 1892 Die Nervenursprünge und Endigungen im Jacobson'schen Organ des Kaninchens. Anat. Anz., Bd. 7, S. 628.

1911 Das Ganglion ciliare der Vögel. Arch. f. Mikros. Anat. u. Entwick., Bd. 76, S. 745.

Weber, ERnst 1908 Über die Selbständigkeit des Gehirns in der Regulierung seiner Blutversorgung. Arch. f. Phys. u. Anat., Phys. Abteil., S. 457.

WIgGers, C. J. 1905 Action of adrenalin on the cerebral vessels. Amer. Jour. Physiol., vol. 14, p. 452.

1907 The innervation of the cerbral vessels as indicated by the action of drugs. Amer. Jour. Physiol., vol. 20, p. 206.

1908 Some vasomotor changes in the cerebral vessels obtained by stimulating the carotid plexuses. Amer. Jour. Physiol., vol. 21, p. 454 . 